\title{
Cellular and mitochondrial mechanisms of atrial fibrillation
}

\author{
Fleur E. Mason ${ }^{1,2} \cdot$ Julius Ryan D. Pronto ${ }^{1,2} \cdot$ Khaled Alhussini ${ }^{3} \cdot$ Christoph Maack $^{4,5}\left(\right.$ Niels Voigt $^{1,2,6} \mathbb{D}$
}

Received: 13 May 2020 / Accepted: 26 October 2020 / Published online: 30 November 2020

(c) The Author(s) 2020

\begin{abstract}
The molecular mechanisms underlying atrial fibrillation (AF), the most common form of arrhythmia, are poorly understood and therefore target-specific treatment options remain an unmet clinical need. Excitation-contraction coupling in cardiac myocytes requires high amounts of adenosine triphosphate (ATP), which is replenished by oxidative phosphorylation in mitochondria. Calcium $\left(\mathrm{Ca}^{2+}\right)$ is a key regulator of mitochondrial function by stimulating the Krebs cycle, which produces nicotinamide adenine dinucleotide for ATP production at the electron transport chain and nicotinamide adenine dinucleotide phosphate for the elimination of reactive oxygen species (ROS). While it is now well established that mitochondrial dysfunction plays an important role in the pathophysiology of heart failure, this has been less investigated in atrial myocytes in AF. Considering the high prevalence of $\mathrm{AF}$, investigating the role of mitochondria in this disease may guide the path towards new therapeutic targets. In this review, we discuss the importance of mitochondrial $\mathrm{Ca}^{2+}$ handling in regulating ATP production and mitochondrial ROS emission and how alterations, particularly in these aspects of mitochondrial activity, may play a role in AF. In addition to describing research advances, we highlight areas in which further studies are required to elucidate the role of mitochondria in AF.
\end{abstract}

Keywords Atrial fibrillation · Mitochondria $\cdot$ Electrophysiology $\cdot$ Oxidative stress $\cdot$ Calcium $\cdot$ Atrial cardiomyopathy

\section{Introduction}

Atrial fibrillation (AF) is the most common sustained arrhythmia and causes substantial morbidity and mortality, particularly due to embolic stroke [5, 88]. Currently

Fleur E. Mason and Julius Ryan D. Pronto contributed equally to this work.

Electronic supplementary material The online version of this article (https://doi.org/10.1007/s00395-020-00827-7) contains supplementary material, which is available to authorized users.

Christoph Maack

Maack_C@ukw.de

$\triangle$ Niels Voigt

niels.voigt@med.uni-goettingen.de

1 Institute of Pharmacology and Toxicology, University Medical Center Göttingen, Georg-August University Göttingen, Robert-Koch-Straße 40, 37075 Göttingen, Germany

2 DZHK (German Center for Cardiovascular Research), Partner Site Göttingen, Göttingen, Germany

3 Department of Thoracic and Cardiovascular Surgery, University Clinic Würzburg, Würzburg, Germany available AF therapies have limited efficacy and safety, particularly in patients with long-standing persistent ('chronic') $\mathrm{AF}$ (cAF). A greater understanding of the molecular mechanisms promoting AF is expected to facilitate the development of improved and better-targeted anti-AF therapies [33, 48].

The underlying mechanisms initiating and promoting $\mathrm{AF}$ are incompletely resolved [81]. However, calcium $\left(\mathrm{Ca}^{2+}\right)$ handling abnormalities and oxidative stress are thought to play central roles in the pathophysiology of AF.

4 Department of Translational Research, Comprehensive Heart Failure Center Würzburg, University Clinic Würzburg, Am Schwarzenberg 15, 97078 Würzburg, Germany

5 Department of Internal Medicine I, University Clinic Würzburg, Am Schwarzenberg 15, 97078 Würzburg, Germany

6 Cluster of Excellence "Multiscale Bioimaging: From Molecular Machines to Networks of Excitable Cells" (MBExC), University of Göttingen, Göttingen, Germany 
Mitochondria are the main producers of cellular adenosine triphosphate (ATP) in cardiac myocytes, and both $\mathrm{Ca}^{2+}$ and adenosine diphosphate (ADP) are key regulators of respiratory flux to match energy supply to the constantly varying demands in the heart $[16,63]$. In mitochondria, the Krebs cycle is fuelled by products of glycolysis and fatty acid $\beta$-oxidation and produces nicotinamide adenine dinucleotide $(\mathrm{NADH})$ and flavin adenine dinucleotide $\left(\mathrm{FADH}_{2}\right)$, which donate electrons to complexes I and II of the electron transport chain (ETC), respectively. Through sequential redox reactions along the ETC, protons are translocated across the inner mitochondrial membrane, establishing a proton gradient which is harnessed by the $F_{1} / F_{\mathrm{o}}$ ATP-synthase to phosphorylate ADP to ATP. During a physiological increase in workload, $\beta$-adrenergic stimulation increases the rate and amplitude of cytosolic $\mathrm{Ca}^{2+}$ transients which, on the one hand, increases ATP consumption. The ensuing increase in ADP flux to the ATPase drains electrons from NADH into the ETC ("pull conditions"), which per se would oxidise NADH. However, the increase in cytosolic $\mathrm{Ca}^{2+}$ transient amplitude and frequency increases $\mathrm{Ca}^{2+}$ uptake into mitochondria via the $\mathrm{Ca}^{2+}$ uniporter (MCU). Since mitochondrial $\mathrm{Ca}^{2+}$ uptake is fast, but extrusion is slower, heart (or myocyte) stimulation rate strongly controls mitochondrial $\mathrm{Ca}^{2+}$ accumulation [16].

Accumulation of $\mathrm{Ca}^{2+}$ subsequently increases the production of electron donors, the reduced forms of NADH and $\mathrm{FADH}_{2}$, used by the electron transport chain to produce ATP via oxidative phosphorylation. However, this "push condition" contributes to reactive oxygen species (ROS) production at the ETC which, when in excess, results in oxidative stress, as discussed later. Since oxidative stress is associated with $\mathrm{AF}$ and its risk factors, the mitochondria could be a

\section{Human studies (31)}

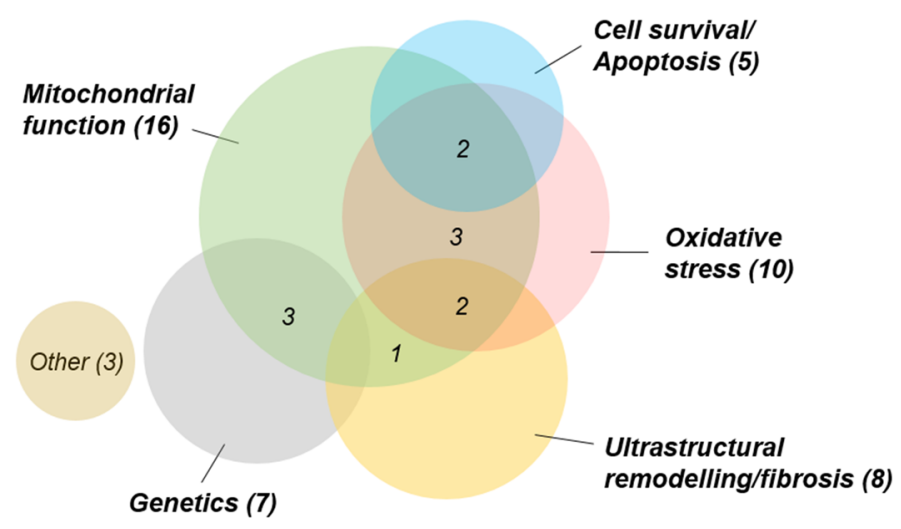

Fig. 1 Results of a medical subject headings (MeSH) publication search in PubMed with categorisation. MeSH terms: "Atrial fibrillation" and "Mitochondria". Relevant publications cited in the cur- potential upstream target for anti-AF therapeutics [110, 124, 125]. Extensive research on ventricular bioenergetics and the ensuing changes in heart failure has paved the way towards testing of mitochondria-targeted therapies, but this is not yet the case in AF [49]. Despite the obvious alterations in myocardial energy demand at increased stimulation frequency in $\mathrm{AF}$, there is a scarcity of literature investigating how much of a role mitochondria play in the pathophysiology of AF. A Medical Subject Headings (MeSH) term search in PubMed, searching for "Atrial fibrillation" and "Mitochondria" yields very few results (Fig. 1 and Supplementary Material). In the first section of this review, we provide an overview of AF pathophysiology and general mitochondrial physiology before reviewing; in the second section, the existing literature associating mitochondrial dysfunction with AF. Furthermore, we discuss ideas how impaired mitochondrial function, especially with regard to $\mathrm{Ca}^{2+}$ handling, could contribute to a pro-arrhythmic substrate and we identify targets for future research.

\section{Pathophysiology of atrial fibrillation}

The most accepted mechanisms underlying AF are reentry and ectopic activity (Fig. 2) [49, 121, 129]. Re-entry describes a pathophysiological concept based on continued impulse propagation around a functional or structural obstacle. Occurrence of re-entry requires a vulnerable substrate and a trigger to initiate re-entry. AF is associated with electrical remodelling of various ion currents, resulting in reentry-promoting shortening of atrial repolarisation, as previously reviewed [49]. This is exacerbated by fibrosis which is thought to play a central role in the pathophysiology of

\section{Animal studies (17)}

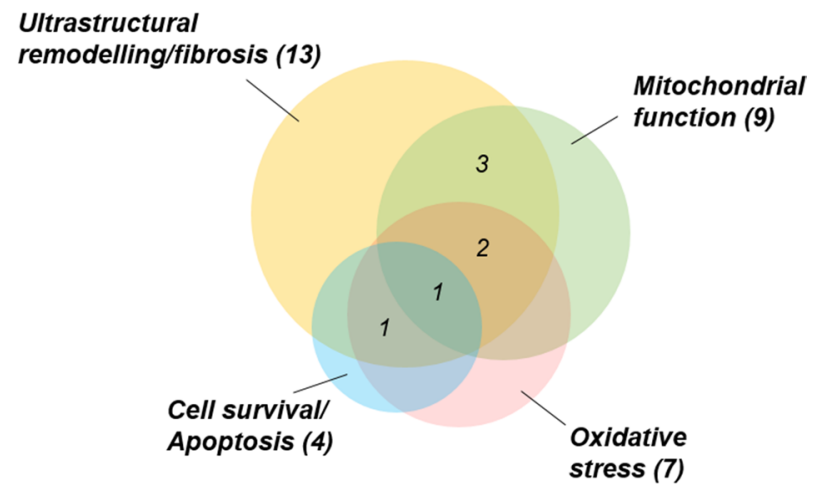

rent review are also included. Review and editorial publications are excluded. Publications are listed in the Electronic Supplementary Material 
Fig. 2 General mechanisms of atrial fibrillation and the potential involvement of disturbed mitochondrial $\mathrm{Ca}^{2+}$ handling. Re-entry requires a vulnerable substrate and trigger for initiation. Ectopic activity can maintain re-entry behaviour. APD, action potential duration; DAD, delayed afterdepolarisation (adapted from Heijman et al. [48])

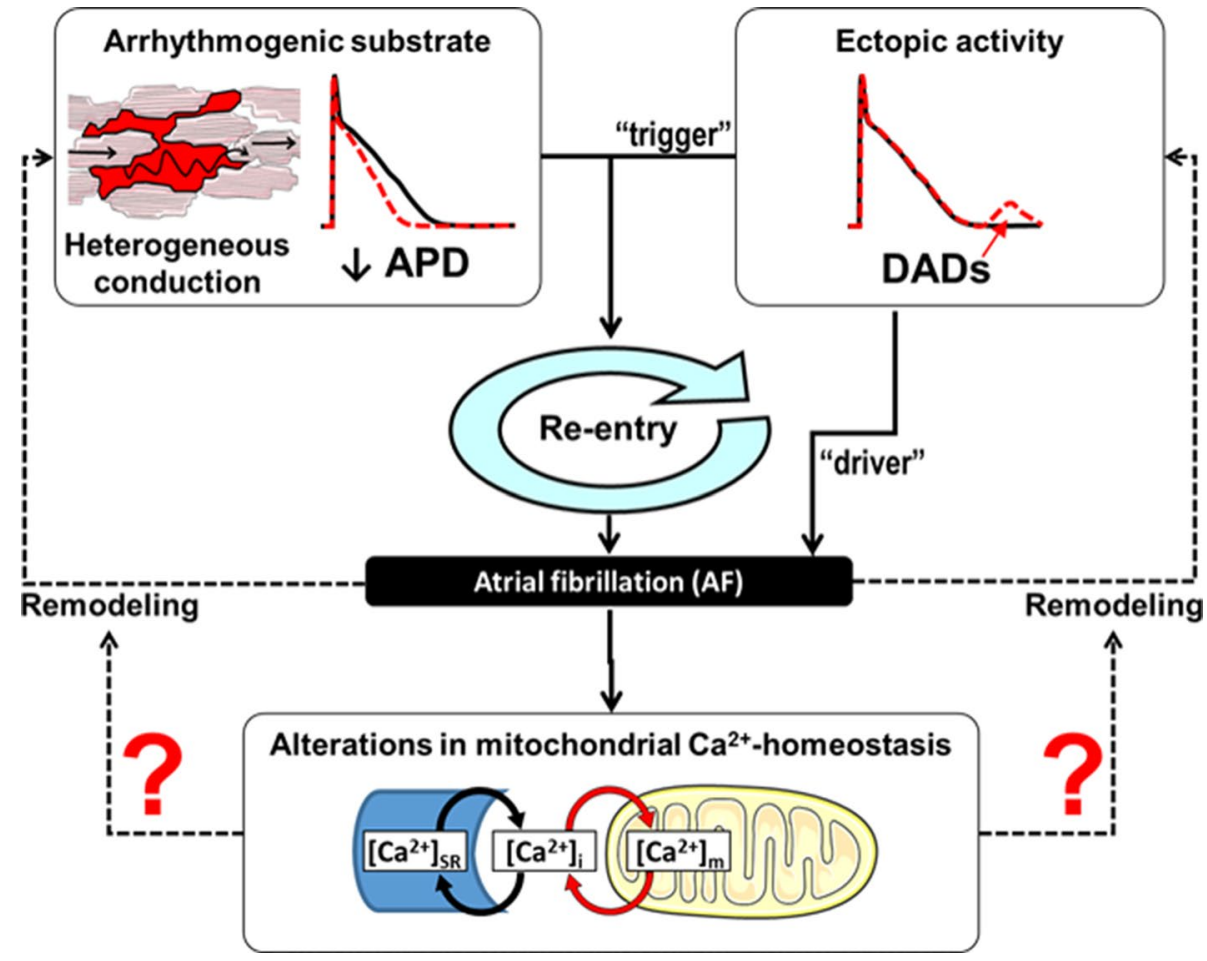

AF, providing a substrate for re-entry and its stabilisation [94]. Spatially discordant electrical alterations in excitability (alternans) cause electrical heterogeneity, favouring initiation and maintenance of AF. Ectopic activity describes abnormal impulse generation outside the sino-atrial node which can act as such a trigger for re-entry. Various publications, as recently reviewed by Denham et al., indicate that disturbances in intracellular $\mathrm{Ca}^{2+}$ handling may play a critical role in the development of ectopic activity, as discussed later [32]. Furthermore, ectopic activity, when occurring repetitively at high frequencies, can maintain the arrhythmia as a so-called "driver". An example of abnormal impulse generation is triggered activity, such as delayed afterdepolarisations (DADs). Indeed, there is evidence in human cardiac myocytes implicating DADs as an underlying cause of both chronic and paroxysmal AF [117, 118].

\section{Abnormal $\mathrm{Ca}^{2+}$ handling contributes to initiation and maintenance of $\mathrm{AF}$}

$\mathrm{Ca}^{2+}$ enters cardiac myocytes through voltage-gated L-type $\mathrm{Ca}^{2+}$ channels $\left(\mathrm{Ca}^{2+}\right.$ current, $\left.I_{\mathrm{Ca}, \mathrm{L}}\right)$ and activates ryanodine receptors (RyR2) located in the sarcoplasmic reticulum (SR), triggering a much larger $\mathrm{Ca}^{2+}$ release than the initiating signal $\left(\mathrm{Ca}^{2+}\right.$-induced $\mathrm{Ca}^{2+}$ release, $\left.\mathrm{CICR}\right)$. The released $\mathrm{Ca}^{2+}$ binds to contractile proteins, causing contraction, and the entire process has been coined excitation-contraction coupling, as reviewed by Bers [15]. The subsequent removal of cytosolic $\mathrm{Ca}^{2+}\left(\left[\mathrm{Ca}^{2+}\right]_{\mathrm{i}}\right)$ allows diastolic relaxation and cardiac filling. Main $\mathrm{Ca}^{2+}$ removal mechanisms are the SR $\mathrm{Ca}^{2+}$-ATPase (SERCA2a), which pumps $\mathrm{Ca}^{2+}$ back into the SR, and the sodium-calcium exchanger (NCX1), which brings $3 \mathrm{Na}^{+}$ions into the cell per extruded $\mathrm{Ca}^{2+}$ ion. The extent to which mitochondrial $\mathrm{Ca}^{2+}$ uptake shapes the systolic $\mathrm{Ca}^{2+}$ transient remains somewhat controversial; however, the current consensus is that it has little effect on the free cytosolic $\mathrm{Ca}^{2+}$ concentration [16].

Pathological beat-to-beat alterations (alternans) in SR $\mathrm{Ca}^{2+}$ release can be translated into alterations of action potential duration (APD) - the aforementioned electrical alternans, as demonstrated in a sheep model by Pearman and colleagues [101]. This is presumably due to the close coupling of $\left[\mathrm{Ca}^{2+}\right]_{i}$ with $\mathrm{Ca}^{2+}$-dependent ion channels and transporters such as L-type $\mathrm{Ca}^{2+}$ channel and NCX1. $\left[\mathrm{Ca}^{2+}\right]_{\mathrm{i}}$-driven alternans is enhanced by factors increasing SR $\mathrm{Ca}^{2+}$ release and by factors reducing $\mathrm{Ca}^{2+}$ sequestration from the cytosol, such as increased $\mathrm{SR} \mathrm{Ca}^{2+}$ leak and reduced SERCA expression or activity (for example due to reduced ATP levels) [34, 37]. Since electrical alternans has been linked to metabolic oscillations, it is plausible that mitochondrial dysfunction-related alternans may also contribute to arrhythmogenesis in AF [98]. Such oscillations in myocytes and whole heart depend on increased levels of ROS, as discussed later in further detail [2, 7, 29].

Increased open probability of RyR 2 predisposes to spontaneous (non-AP-triggered) diastolic $\mathrm{SR} \mathrm{Ca}^{2+}$ release events (SCaEs) [27, 52, 95, 118]. CaMKII-mediated hyperphosphorylation of RyR2 contributes to RyR2 dysfunction in AF [50, 
118]. Greater intracellular $\mathrm{Ca}^{2+}$ leak, together with increased NCX1 function, promotes the aforementioned DADs, which have the potential to trigger extrasystolic activity [118]. Intracellular $\mathrm{Ca}^{2+}$ overload, secondary to intracellular $\mathrm{Na}^{+}$ overload, also leads to this type of activity, as previously reviewed [80].

\section{Mitochondrial physiology in the heart}

\section{Mitochondrial $\mathrm{Ca}^{2+}$ homeostasis in cardiac myocytes}

The importance of $\mathrm{Ca}^{2+}$ in the mitochondrial matrix $\left(\left[\mathrm{Ca}^{2+}\right]_{\mathrm{m}}\right)$ for regulation of mitochondrial function was suggested as far back as 30 years ago [83]. Although the kinetics of mitochondrial $\mathrm{Ca}^{2+}$ cycling and contribution to cytosolic $\left[\mathrm{Ca}^{2+}\right]$ remain highly controversial, it is well accepted that $\mathrm{Ca}^{2+}$ regulates ATP production and ROS signalling and plays a crucial role in mitochondrial-determined cell death [16]. Furthermore, the coupling between cytosolic and mitochondrial $\mathrm{Ca}^{2+}$ increases ATP synthesis in response to increased cardiac activity, thus matching cellular ATP supply to demand [59]. Considering that $\mathrm{Ca}^{2+}$ is important in the regulation of mitochondrial function, it is conceivable that altered cytosolic $\mathrm{Ca}^{2+}$ dynamics may affect mitochondrial $\mathrm{Ca}^{2+}$ handling and energetics (Fig. 2). While the majority of previous studies on cardiac mitochondria have been conducted in ventricular myocytes or tissue, it has been revealed that mitochondria may buffer centripetal diffusion of $\mathrm{Ca}^{2+}$ in atrial myocytes and there is evidence that mitochondrial distribution and density vary between atrial and ventricular tissue [20, 77, 84]. Therefore, atrialspecific properties of mitochondria is an area warranting further investigation. Furthermore, since mitochondrial dysfunction has been implicated in heart failure, it will be important to ascertain whether-or how-mitochondria are associated with atrial pathological processes, such as those occurring in AF.

\section{Kinetics of mitochondrial $\mathrm{Ca}^{2+}$ transients}

The kinetics of mitochondrial $\mathrm{Ca}^{2+}$ uptake are still a matter of debate. It has been suggested that mitochondria take up and release $\mathrm{Ca}^{2+}$ during each heart beat (Fig. 3a, Model I: Oscillator) or that they may act as integrators, taking up $\mathrm{Ca}^{2+}$ gradually in response to increased cytosolic $\mathrm{Ca}^{2+}$, resulting in an increase in steady state $\left[\mathrm{Ca}^{2+}\right]_{\mathrm{m}}$ (Fig. 3a, Model II: Integrator) [75]. Difficulties in measuring $\left[\mathrm{Ca}^{2+}\right]_{\mathrm{m}}$ with membrane-permeable fluorescent ester indicators likely contribute to the uncertainty as to which model is correct [75]. There is, however, evidence for both models in combination (Fig. 3b, c) $[6,69,74]$. It appears that $\left[\mathrm{Ca}^{2+}\right]_{\mathrm{m}}$ transients can occur with each cytosolic $\mathrm{Ca}^{2+}$ transient, and that diastolic $\left[\mathrm{Ca}^{2+}\right]_{\mathrm{m}}$ increases progressively at higher stimulation a

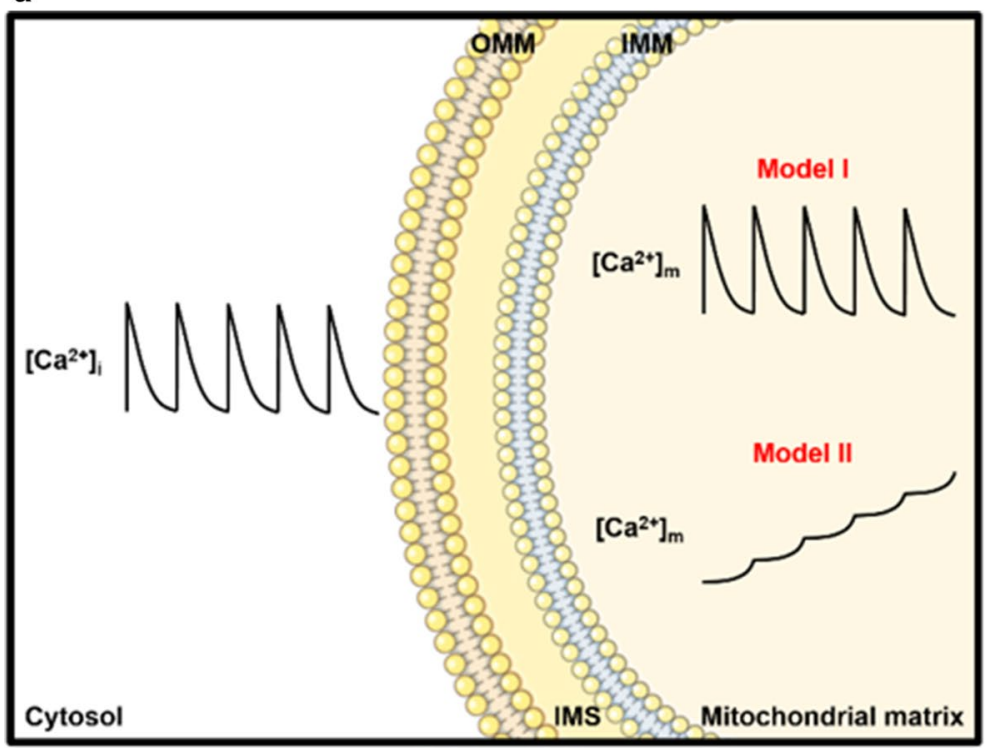

b

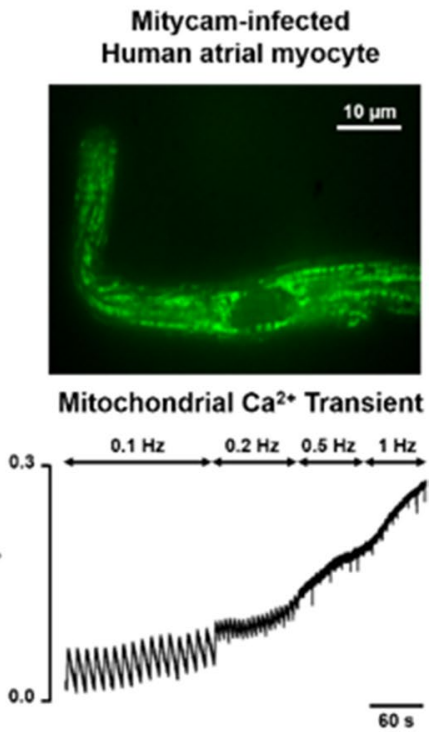

Fig. 3 Dynamics of mitochondrial $\mathrm{Ca}^{2+}$. a Models of transmission of fast cytosolic $\mathrm{Ca}^{2+}$ transients $\left(\left[\mathrm{Ca}^{2+}\right]_{\mathrm{i}}\right)$ to mitochondrial $\mathrm{Ca}^{2+}\left(\left[\mathrm{Ca}^{2+}\right]_{\mathrm{m}}\right)$. Model I: rapid, beat-to-beat transmission; Model II: slow integration of $\left[\mathrm{Ca}^{2+}\right]_{i}$ oscillations. IMM, inner mitochondrial membrane; IMS, intermembrane space; OMM, outer mitochondrial membrane. b Fluorescent image of a Mitycam-infected human atrial myocyte (measurement of $\left[\mathrm{Ca}^{2+}\right]_{\mathrm{m}}$.) c) Representative record- ing of Mitycam fluorescence in response to increasing stimulation frequency in a human atrial myocyte (unpublished). This figure was created using images from Servier Medical Art Commons Attribution 3.0 Unported License. (http://smart.servier.com). Servier Medical Art by Servier is licensed under a Creative Commons Attribution 3.0 Unported License 
frequencies or cellular $\mathrm{Ca}^{2+}$ loading. Whereas the oscillator model seems to be relevant at lower stimulation frequencies, the integrator model is thought to dominate at higher frequencies, which is important for matching ATP production to demand. Moreover, peak $\mathrm{Ca}^{2+}$ uptake in the mitochondria appears to occur faster than cytosolic $\mathrm{Ca}^{2+}$ increase, supporting the concept of a $\mathrm{Ca}^{2+}$ microdomain between the SR and mitochondria that is necessary for efficient $\mathrm{Ca}^{2+}$ uptake $[58,74]$.

\section{Mitochondrial $\mathrm{Ca}^{2+}$-influx and -efflux pathways}

The major mitochondrial $\mathrm{Ca}^{2+}$-influx and -efflux pathways are summarised in Fig. 4. Mitochondrial $\mathrm{Ca}^{2+}$ microdomains necessary for $\mathrm{Ca}^{2+}$ influx are spatially distinct from $\mathrm{Ca}^{2+}$ efflux mechanisms, and this is likely to be important for efficient $\mathrm{Ca}^{2+}$ signalling and excitation-energetics coupling [62]. The mitochondrial matrix is separated from the cytosol by two membranes which need to be passed for exchange of metabolites, adenine nucleotides and cations, including regulators of mitochondrial activity such as $\mathrm{Ca}^{2+}$. A voltage-dependent anion channel (VDAC) allows $\mathrm{Ca}^{2+}$ to pass across the outer mitochondrial membrane, and thus plays a role in mediating mitochondrial $\mathrm{Ca}^{2+}$ uptake $[104,123]$. The relative low permeability of the inner mitochondrial membrane (IMM) to ions is required to maintain the strongly negative membrane potential between the intermembrane space and the mitochondrial matrix $\left(\Delta \Psi_{\mathrm{m}} \approx-180 \mathrm{mV}\right)$. Ions can only pass into the mitochondrial matrix via specialised channels and transporters. Several mechanisms have been described for mitochondrial $\mathrm{Ca}^{2+}$ uptake, all driven by the large $\Delta \Psi_{\mathrm{m}}$ across the IMM. The best-characterised pathway is the mitochondrial $\mathrm{Ca}^{2+}$ uniporter (MCU) [61, 112]. The $\mathrm{MCU}$ is regulated by divalent cations, ruthenium compounds and adenine nucleotides. The $\mathrm{Ca}^{2+}$-binding protein MICU1 (mitochondrial $\mathrm{Ca}^{2+}$ uptake 1) is likely required for mitochondrial $\mathrm{Ca}^{2+}$ uptake and may act as an auxiliary regulatory protein, determining the $\left[\mathrm{Ca}^{2+}\right]_{\mathrm{m}}$ threshold for $\mathrm{Ca}^{2+}$ uptake and preventing mitochondrial $\mathrm{Ca}^{2+}$ overload. Low $\mathrm{Ca}^{2+}$ affinity $\left(K_{\mathrm{m}} \approx 10-20 \mu \mathrm{M}\right)$ is a critical property of the MCU, making mitochondrial proximity to microdomains of high $\left[\mathrm{Ca}^{2+}\right]_{\mathrm{i}}$ (e.g. RyR2) a requirement for effective mitochondrial $\mathrm{Ca}^{2+}$ uptake. The importance of this proximity has been demonstrated by $\mathrm{Lu}$ and colleagues in rabbit ventricular myocytes transfected with a genetically encoded mitochondrial $\mathrm{Ca}^{2+}$ sensor (Mitycam); it was found that mitochondrial $\mathrm{Ca}^{2+}$ uptake is greater and faster near $\mathrm{SR} \mathrm{Ca}^{2+}$ release sites (Z-line of sarcomere), compared to the middle of the sarcomere (M-line), where SR $\mathrm{Ca}^{2+}$ release is limited and MCU density is lower [69]. The role of the mitochondrial MCU complex during basal metabolism versus stress conditions has been extensively discussed by others but the exact involvement of the MCU during pathophysiology remains to be elucidated [41, 47].

Two other potential avenues of $\mathrm{Ca}^{2+}$ entry into mitochondria are rapid-mode mitochondrial $\mathrm{Ca}^{2+}$ uptake $(\mathrm{RaM})$ and mitochondrial RyRs (mRyR1), as reviewed by De Stefani et al. [113]. RaM was found in heart mitochondria after its initial discovery in liver [23]. However, RaM is thought to be negligible during physiological $\left[\mathrm{Ca}^{2+}\right]_{\mathrm{i}}$ changes in cardiac myocytes because of its slow recovery from inactivation. In contrast, mRyR 1 allows $\mathrm{Ca}^{2+}$ sequestration at low cytosolic $\mathrm{Ca}^{2+}$ concentrations and therefore it could contribute to physiological beat-to-beat $\mathrm{Ca}^{2+}$ uptake in the heart [17]. Furthermore, there are data showing that mitochondrial RyR1 may also be important in slower uptake of inositol 1,4,5-triphosphate receptor $\left(\mathrm{IP}_{3} \mathrm{R}\right)$-mediated $\mathrm{SR} \mathrm{Ca}^{2+}$ release [106, 107].

Mitochondrial $\mathrm{Ca}^{2+}$ extrusion pathways comprise both $\mathrm{Na}^{+}$-dependent and $\mathrm{Na}^{+}$-independent mechanisms. However, in cardiac mitochondria, the mitochondrial $\mathrm{Na}^{+}-\mathrm{Ca}^{2+}$ exchanger (mNCX or NCLX $\left[\mathrm{Na}^{+} / \mathrm{Ca}^{2+} / \mathrm{Li}^{+}\right.$exchanger]) is suggested to be the predominant $\mathrm{Ca}^{2+}$ extrusion mechanism $[24,100]$. Moreover, lethality observed in NCLX-KO mice was attributed to mitochondrial $\mathrm{Ca}^{2+}$ overload, which consequently results in cardiac remodelling and dysfunction [71]. It is widely accepted that NCLX is electrogenic and exchanges $3 \mathrm{Na}^{+}$ions per extruded $\mathrm{Ca}^{2+}$ ion, favouring $\mathrm{Ca}^{2+}$ extrusion due to the highly negative $\Delta \Psi_{\mathrm{m}}$ [90]. To maintain intra-mitochondrial $\mathrm{Na}^{+}$concentration, $\mathrm{Na}^{+}$is removed from the mitochondrial matrix by a $\mathrm{Na}^{+}-\mathrm{H}^{+}$exchanger (mNHE) located in the IMM. Of note, NCLX develops half-maximal activity in the physiological range of cytosolic $\mathrm{Na}^{+}$, making NCLX sensitive to physiological $\mathrm{Na}^{+}$fluctuations and the cytosol-matrix $\mathrm{Na}^{+}$gradient, as previously reviewed [14, $16,90,122]$.

\section{Mitochondrial $\mathrm{Ca}^{2+}$ regulates mitochondrial function}

\section{Mitochondrial ATP synthesis}

It has been shown in non-ischaemic ventricular myocytes that almost all ATP is derived from mitochondrial oxidative phosphorylation, with the remainder from glycolysis and GTP formation in the Krebs cycle. During oxidative phosphorylation, four multi-protein complexes (Complexes I-IV) which make up the aforementioned ETC, located in the IMM, catalyse electron transport from NADH and $\mathrm{FADH}_{2}$ to oxygen. The energy released by electron transport allows Complexes I, III and IV to pump protons from the mitochondrial matrix into the intermembrane space; the resulting proton gradient across the IMM contributes to the electrochemical gradient $\left(\Delta \Psi_{\mathrm{m}}\right)$, which fuels ATP synthesis by $F_{1} / F_{\mathrm{o}}$ ATP-synthase (also known as Complex V) (Fig. 4). 


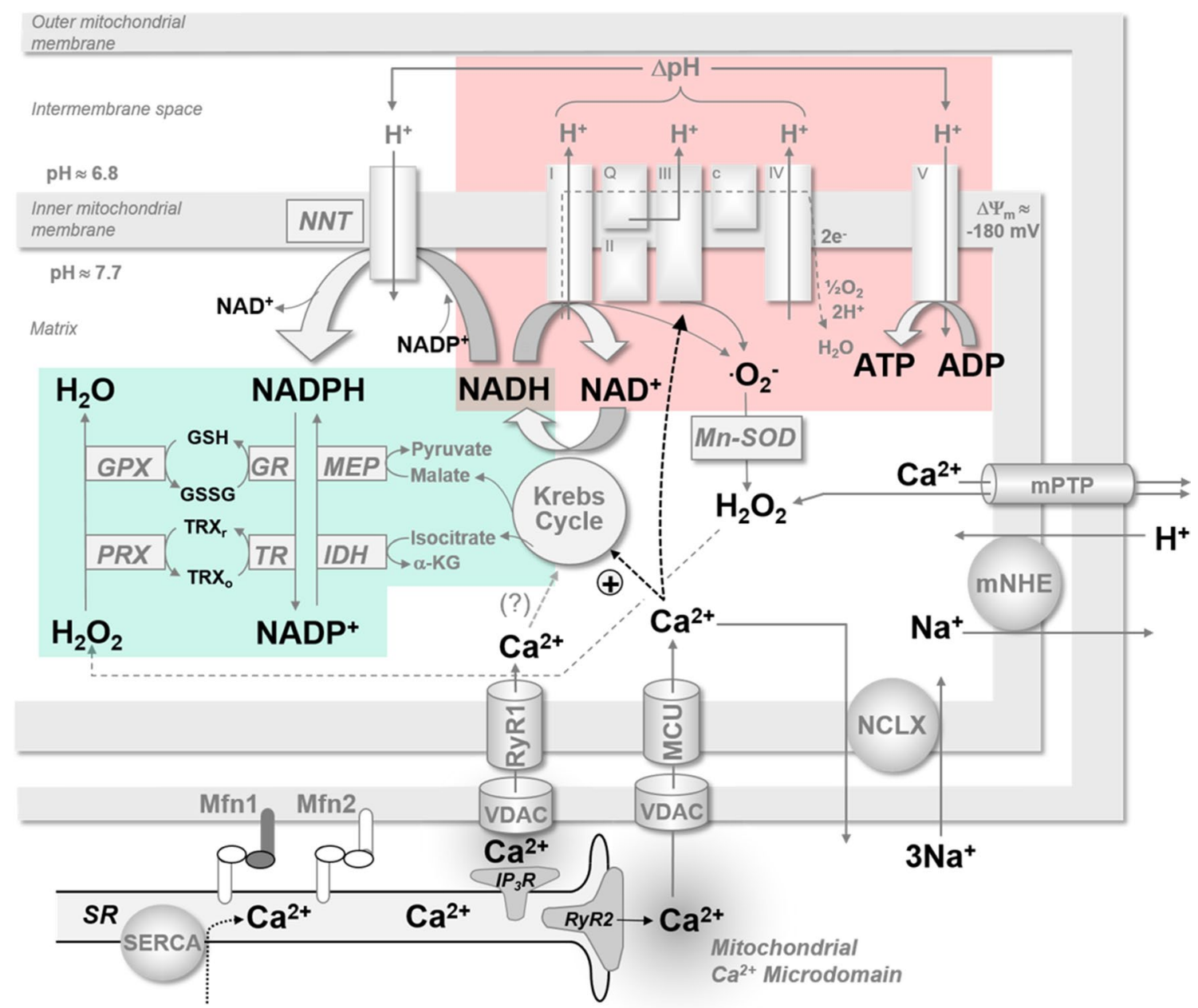

Fig. 4 Major mitochondrial $\mathrm{Ca}^{2+}$-influx and -efflux pathways, mitochondrial ATP production and ROS elimination. $\mathrm{Ca}^{2+}$ is released by the sarcoplasmic reticulum (SR) via type 2 ryanodine receptors (RyR2) and passes through the outer mitochondrial membrane via voltage-dependent anion channels (VDAC). $\mathrm{Ca}^{2+}$ enters the mitochondrial matrix via the mitochondrial $\mathrm{Ca}^{2+}$ uniporter (MCU) in the inner mitochondrial membrane. Mitochondrial ryanodine receptor type 1 (RyR1) may play a role in taking up $\mathrm{Ca}^{2+}$ released more slowly from the SR via inositol 1,4,5-triphosphate receptors $\left(\mathrm{IP}_{3} \mathrm{R}\right)$. Microdomains of high $\left[\mathrm{Ca}^{2+}\right]$ are created due to the close proximity of SR and mitochondria through membrane tethering by mitofusin 1 and 2 (Mfn1 and Mfn2). Mitochondrial $\mathrm{Ca}^{2+}$ is extruded on the $\mathrm{Na}^{+} /$ $\mathrm{Ca}^{2+} / \mathrm{Li}^{+}$exchanger (NCLX). The mitochondrial permeability transmission pore (mPTP) opens upon $\mathrm{Ca}^{2+}$ overload and plays a role in cell death and ROS-induced ROS release (RIRR). Matrix $\mathrm{Ca}^{2+}$ activates Krebs cycle dehydrogenases, regenerating the reduced form of NADH (nicotinamide adenine dinucleotide) which donates elec-

It is thought that there is a complete turnover of the myocardial ATP pool in less than a minute under normal conditions and, depending on heart rate, this may be as quick as every $10 \mathrm{~s}$ [111]. Therefore, there is need for tight regulation of mitochondrial ATP production to meet varying metabolic demands resulting from beat-to-beat changes in trons to the electron transport chain (ETC). Electron flow in the ETC causes protons to be translocated into the intermembrane space, contributing to an electrochemical gradient across the inner mitochondrial membrane $\left(\Delta \Psi_{\mathrm{m}}\right)$ which is used to drive ATP production by the $F_{1} / F_{\mathrm{o}}$ ATP-synthase (Complex V). Complexes I and III of the ETC produce superoxide $\left(\mathrm{O}_{2}^{-}\right)$which is subsequently converted to $\mathrm{H}_{2} \mathrm{O}_{2}$ by superoxide dismutase (Mn-SOD). $\mathrm{H}_{2} \mathrm{O}_{2}$ is eliminated by peroxiredoxin (PRX) and glutathione peroxidase (GPX), which require reduced NADPH (nicotinamide adenine dinucleotide phosphate) for regeneration. NADPH is regenerated by isocitrate dehydrogenase (IDH) and malic enzyme (MEP) and nicotinamide nucleotide transhydrogenase (NNT). $\alpha$-KG $\alpha$-ketoglutarate, I-IV complexes I-IV of the ETC, $Q$ Q-cycle, $\Delta p H$ proton gradient; mNHE, mitochondrial $\mathrm{Na}^{+}-\mathrm{H}^{+}$exchanger, SERCA SR Ca ${ }^{2+}$-ATPase, GSH/GSSG reduced/ oxidised glutathione, $G R$ glutathione reductase, $T R X_{r} / T R X_{o}$ reduced/ oxidised thioredoxin, $T R$ thioredoxin reductase (adapted from Nickel et al. [96])

cardiac workload. Two major regulators of oxidative phosphorylation have been proposed: (1) the products of ATP hydrolysis itself (ADP and $\mathrm{P}_{\mathrm{i}}$ ) and (2) $\mathrm{Ca}^{2+}$. The classical hypothesis was based on measurements of oxygen consumption in isolated mitochondria [64]. ADP and $P_{\mathrm{i}}$ directly stimulate the $F_{1} / F_{\mathrm{o}}$-ATP synthase, thus acting as a "pull" 
on oxidative phosphorylation and causing NADH oxidation. This hypothesis, however, has been challenged by the finding that large changes in cardiac work and ATP consumption in vivo are not associated with measurable changes in $\mathrm{ADP} / P_{\mathrm{i}}$ [9]. An increased workload requires increased time-averaged $\left[\mathrm{Ca}^{2+}\right]_{\mathrm{i}}$. This also acts to increase $\left[\mathrm{Ca}^{2+}\right]_{\mathrm{m}}$. $\left[\mathrm{Ca}^{2+}\right]_{\mathrm{m}}$ stimulates substrate flow through the Krebs cycle by directly activating key enzymes, thereby increasing production of NADH and $\mathrm{FADH}_{2}$, fuelling oxidative phosphorylation and increasing ATP production $[18,58]$. In addition, mitochondrial $\mathrm{Ca}^{2+}$ is thought to directly stimulate the $F_{1} / F_{\text {o }}$ ATP-synthase and possibly Complex III of the ETC, thus increasing the rate of oxidative phosphorylation $[89,114]$. $\mathrm{IP}_{3} \mathrm{R}$, activated by endothelin signalling, may also play an important role in the bioenergetics of cardiac myocytes by inducing mRyR1-mediated $\mathrm{Ca}^{2+}$ entry and consequently stimulating mitochondrial ATP production. This is thought to be due to close interaction between the SR and mitochondria, facilitated by mitofusin 2 (Mfn2) [106, 107].

\section{Mitochondrial ROS production and elimination}

Reactive oxygen species (ROS) in the mitochondria result from the single-electron reduction of molecular oxygen $\left(\mathrm{O}_{2}\right)$ during oxidative phosphorylation, among other less significant pathways [91]. Since $\mathrm{O}_{2}$ is preferentially partitioned in biological membranes where it can interact with electron carriers, such as in the ETC, mitochondria are considered to be a major source of ROS in the cell [10, 91]. Experimentally, 1-2\% of oxygen consumed ends up in ROS production at the ETC, primarily at Complexes I and III, although this is estimated to be considerably less in vivo [91]. The first product of the monovalent reduction of $\mathrm{O}_{2}$ is superoxide anion $\left(\mathrm{O}_{2}^{-}\right)$. Complex I produces $\mathrm{O}_{2}{ }^{-}$by two mechanisms: (1) a high NADH/NAD ${ }^{+}$ratio results in fully reduced flavin mononucleotide (FMN), thus backing up the electrons, increasing the time for interaction with $\mathrm{O}_{2}$; (2) reverse electron transport (RET) due to a reduced ubiquinone (CoQ) pool, where the rate of $\mathrm{O}_{2}{ }^{-}$production is considered to be highest in the mitochondria [91]. Complex III releases $\mathrm{O}_{2}{ }^{-}$at least partially into the intermembrane space, depending on local ubisemiquinone $\left(\mathrm{Q}^{-}\right)$concentrations in the $b c_{1}$ complex, whereas ROS production and release by Complex I is limited to the matrix [19]. ROS is generated at Complex III via the Q-cycle when, in a reduced state, a halt in the electron flow enables more time for $\mathrm{O}_{2}$ to interact with the reduced electron carrier, $\mathrm{Q}^{-}$[116]. ROS production at Complex III, however, is regarded as inconsequential compared to rate of production at Complex I, unless pharmacologically induced by Antimycin A. Dihidrolipoamide dehydrogenase, a component of the metabolic enzymes $\alpha$-ketoglutarate dehydrogenase $(\alpha \mathrm{KGDH})$ and pyruvate dehydrogenase (PDH), is also capable of ROS production in a NADH/NAD ${ }^{+}$-dependent manner [3, 91, 103]. However, under physiological conditions in working cardiac myocytes, $\alpha-\mathrm{KGDH}$ is not a relevant source of ROS, but rather contributes to regeneration of reduced nicotinamide adenine dinucleotide phosphate (NADPH) through tight functional coupling to the nicotinamide nucleotide transhydrogenase [119]. Further potential sites for ROS production in the mitochondria have been suggested, as reviewed by Murphy [91]. ROS production increases when there is low ATP demand (state 4 respiration), causing a build-up of reduced NADH (electron donors) or when there is damage to the ETC [10]. Furthermore, ROS production in cardiac myocytes rises during increased workload, for example at higher stimulation frequencies [51, 56].

Net mitochondrial ROS emission from mitochondria is determined not only by the ROS formation rate, but also by ROS elimination. ${ }^{\circ} \mathrm{O}_{2}{ }^{-}$is assumed to be present in low picomolar range due to its immediate dismutation by MnSOD [60, 91]. $\mathrm{H}_{2} \mathrm{O}_{2}$, the main ROS signal, is eliminated by peroxiredoxin and glutathione peroxidase, which require NADPH for regeneration, and also by mitochondrial catalase [16]. NADH generated by the Krebs cycle, and in particular, by $\alpha-\mathrm{KGDH}$, is converted to NADPH by nicotinamide nucleotide transhydrogenase (NNT), a process coupled to the proton gradient across the IMM [97, 119]. Furthermore, NADPH is regenerated by isocitrate dehydrogenase and malic enzyme, which also both derive substrates from the Krebs cycle (isocitrate and malate, respectively). Thus mitochondrial anti-oxidative capacity, ROS elimination and net mitochondrial ROS emission are largely dependent on the Krebs cycle turnover rate [16, 59]. Increased mitochondrial $\mathrm{Ca}^{2+}$ uptake and consecutively, enhanced Krebs cycle turnover rate maintain sufficient anti-oxidative capacity of the mitochondrial matrix during increased workload. Accordingly, myocytes from a heart failure model, in which $\left[\mathrm{Ca}^{2+}\right]_{\mathrm{m}}$ elevation in response to increased workload is limited, showed abnormal increases in mitochondrial ROS emission at higher stimulation frequencies [56].

The group of O'Rourke introduced the idea of redoxoptimised ROS balance (R-ORB) [8, 30]. R-ORB conceptualises that the redox environment (RE; calculated from the oxidised and reduced states of mitochondrial redox couples) determines mitochondrial ROS levels, and that an intermediate redox state (maximal energy output, state 3 respiration) is accompanied by minimal ROS emission. At either extreme of the RE, ROS levels increase, albeit through different mechanisms; at extremely reduced RE, ROS formation excels due to increased electron slippage from the ETC and thus ROS production exceeds ROS scavenging. Conversely, in the case of an oxidative shift in the RE, for example during pathological increase in workload during 
heart failure, ROS emission will increase due to reduced ROS-scavenging capacity of the mitochondria, secondary to NNT reversal, as discussed later [97].

\section{Mitochondrial $\mathrm{Ca}^{2+}$ overload}

Mitochondrial $\mathrm{Ca}^{2+}$ overload leads to pathological opening of the mitochondrial permeability transition pore (mPTP), causing a profound decrease in mitochondrial membrane potential and ATP levels which leads to cell death [31, 44]. Interestingly, small, transient and low conductance openings of the PTP (tPTP) have also been identified; however, such openings are believed to be rare and are thought to occur under physiological conditions as a way to release excess mitochondrial $\mathrm{Ca}^{2+}[70]$. The major role of the mPTP in cell death has been reviewed comprehensively elsewhere and will therefore not be the focus of this review $[31,44]$.

\section{Mitochondria and atrial fibrillation}

\section{Ultrastructural remodelling in cardiac pathophysiology}

Subcellular anatomy is thought to be crucial for effective mitochondrial $\mathrm{Ca}^{2+}$ uptake, which requires close interaction between MCU and RyR2 of the SR, as mentioned earlier. In ventricular myocytes, mitochondria are located $\sim 40$ to $300 \mathrm{~nm}$ from the RyR2 and are, therefore, exposed to very high $\left[\mathrm{Ca}^{2+}\right]_{\mathrm{i}}(10-20 \mu \mathrm{M})$, explaining why mitochondrial $\mathrm{Ca}^{2+}$ uptake through MCU is so rapid, despite its relatively low $\mathrm{Ca}^{2+}$ affinity [109]. Thus, as has been observed in ventricular myocytes, mitochondrial $\mathrm{Ca}^{2+}$ uptake efficiency is maximal when $\mathrm{Ca}^{2+}$ is released from the SR, compared to $\mathrm{Ca}^{2+}$ entering the cell via sarcolemmal NCX [57]. This points to RyR2 channels as the major supplier of $\mathrm{Ca}^{2+}$ for the mitochondria and suggests that SR and mitochondria must have close proximity. Molecular tethers such as Mfn2 likely maintain the close structural and functional association between SR and mitochondria. Suppression of Mfn2 in murine embryonic fibroblasts and HeLa cells increases the separation between SR and mitochondria, although this has spurred some controversies [21, 39, 92, 93]. Furthermore, mitochondrial $\mathrm{Ca}^{2+}$ uptake is decreased in ventricular myocytes from Mfn2-deficient mice [26, 107].

The spatial organisation of mitochondria is disrupted in heart failure $[42,72]$ and even as early as the 1980s, the Rosen group observed that ultrastructure of atrial myocytes can also be damaged in response to different cardiac and metabolic diseases, potentially impacting on RyR-mitochondrion interaction [79]. These findings have been supported by a more recent publication, showing that ultrastructural remodelling occurs in the left atrium of patients with $\mathrm{AF}$
[108]. Furthermore, outer mitochondrial membrane disruption has been observed in an AF mouse model with constitutively leaky RyR2, and this may affect physical tethering between the mitochondria and SR [124]. There is also evidence for a RyR2-/VDAC2-containing protein complex, which may play a role in stabilising SR-mitochondrial interaction and which seems to be essential for the transfer of $\mathrm{Ca}^{2+}$ from the SR to the mitochondrial matrix, at least in ventricular cardiac myocytes $[38,86]$. The $\mathrm{IP}_{3} \mathrm{R}$ is thought to play a greater role in the physiology of the atrium than the ventricle and has been shown to contribute to endothelininduced arrhythmic activity in a rat model $[68,76]$. Whether $\mathrm{IP}_{3} \mathrm{R}$-related pathological mechanisms induce or involve mitochondrial dysfunction remains unknown.

\section{Open aspects for future research}

The various interactions between intracellular $\mathrm{Ca}^{2+}$ release sites and mitochondria, to what extent they are altered in $\mathrm{AF}$ and the effects of such changes on mitochondrial $\mathrm{Ca}^{2+}$ uptake remain unclear and therefore represent major targets for future investigation. Previous studies on mitochondrial activity in ventricular cells/tissue will undoubtedly serve as an invaluable basis for the design of atrial studies $[56,69]$. Measurement of atrial mitochondrial (and cytosolic) $\mathrm{Ca}^{2+}$ at high pacing frequencies, as well as MCU function, is likely to be a crucial step in ascertaining the roles of $\mathrm{Ca}^{2+}$ handling dynamics between cytosolic and mitochondrial compartments and whether any alterations occur during - and contribute to-AF pathophysiology.

\section{The potential role of impaired mitochondrial ATP synthesis in atrial fibrillation}

As mentioned previously, the majority of cellular ATP is produced by oxidative phosphorylation in the mitochondria. Emelyanova and colleagues provided evidence for impaired activity of Complexes I and II in right atrial tissue from patients with AF [35]. These findings are in agreement with another recent study which observed impaired complex I and II function in addition to impaired ETC super-complex assembly in patients with diabetes and AF, compared with diabetes alone [54]. Down-regulated expression of various enzymes involved in mitochondrial energy metabolism, for example citrate synthase, has been identified in AF [115]. There is also evidence for pre-operative downregulation of mitochondrial/oxidative phosphorylation gene clusters as well as mitochondrial dysfunction in patients who develop AF after cardiac surgery (post-operative AF) [1, 87]. Animal models of AF have yielded disparate results, for example reduced Complex III and $F_{1} / F_{\mathrm{o}} \mathrm{ATP}$-synthase activity in a canine model of AF [78]. Therefore, further investigation into human AF will add to the current knowledge about 
changes occurring at the level of the ETC and mitochondrial respiration during the disease process.

The Blatter group used pharmacological tools to investigate the effect of impaired mitochondrial ATP synthesis in cat atrial myocytes [128]; cytosolic ATP concentration was unchanged, and it was deduced that increased glycolysis in the cytosol could compensate for lower mitochondrial ATP synthesis. However, there was also an increased frequency of the aforementioned SCaEs, as well as intracellular acidosis, and the authors suggested that increased lactate production (due to glycolysis) leads to acidosis, followed by $\mathrm{Na}^{+}$overload via sarcolemmal $\mathrm{Na}^{+}-\mathrm{H}^{+}$exchanger (NHE) and subsequent $\mathrm{Ca}^{2+}$ overload (via reverse-mode $\mathrm{NCX}$ ), leading to SCaEs, as illustrated in Fig. 5 [128]. As mentioned previously, alterations of intracellular $\mathrm{Ca}^{2+}$ handling are thought to play a central role in the initiation and maintenance of arrhythmic activity, and, therefore, the findings of the Blatter group provide an attractive theory as to how altered mitochondrial function could provide a pro-arrhythmic substrate.

Due to the high stimulation frequency endured during AF, the energy consumption and, therefore, energy requirement of atrial tissue is increased, likely activating the aforementioned "pull" condition at the ETC [59]. It is believed that there are changes affecting supply and delivery of metabolic substrates and oxygen, inducing a state of metabolic stress [45]. We speculate that impaired cytosolic-mitochondrial $\mathrm{Ca}^{2+}$ signalling could also play a role. The initial phase of $\mathrm{AF}$ has been described as a short period of "cellular $\mathrm{Ca}^{2+}$

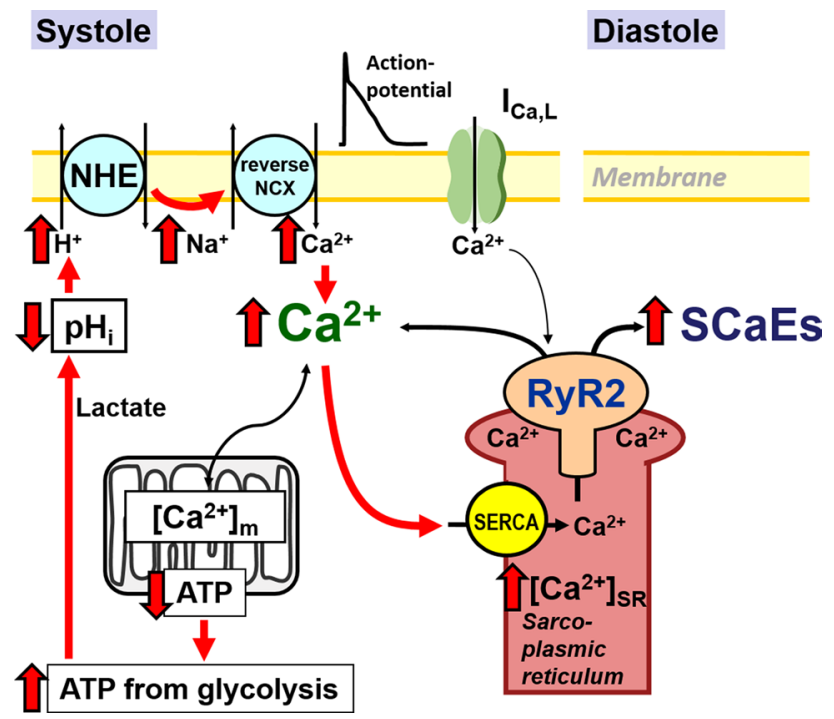

Fig. 5 The impact of reducing mitochondrial ATP production. Compensatory increase in glycolysis reduces intracellular $\mathrm{pH}$, consequently causing intracellular $\mathrm{Na}^{+}$and $\mathrm{Ca}^{2+}$ overload (as suggested by Zima et al. [128]). $I_{C a . L}$ L-type $\mathrm{Ca}^{2+}$ current, $N C X$ sodium-calcium exchanger, $N H E$ sodium-hydrogen exchanger, $R y R 2$ ryanodine receptor type 2, SCaEs spontaneous $\mathrm{Ca}^{2+}$ release events, SERCA SR $\mathrm{Ca}^{2+}$-ATPase overload" on account of increased atrial activation rate, preceding a longer phase involving adaptation and remodelling of electrophysiology and $\mathrm{Ca}^{2+}$ dynamics, coined " $\mathrm{Ca}^{2+}$ silencing", as reviewed by Greiser and Schotten [43]. It is thus plausible that a relative reduction of intracellular $\mathrm{Ca}^{2+}$, after the initial overload period, may contribute to the mismatch of ATP supply to demand in AF, considering the important role of $\mathrm{Ca}^{2+}$ in stimulating mitochondrial ATP production. It may not be the amount of $\mathrm{Ca}^{2+}$ per se entering the mitochondria which is important, but the amount relative to what is required for an increase in ATP production, for the energetic demands of the myocyte to be met.

Of course, many factors determine ATP production and there is increasing evidence that metabolic alterations play a crucial role in cardiac remodelling leading to arrhythmia, including AF, as comprehensively discussed by others $[12,13,45,99]$. An extensive discussion of the metabolic alterations linked to AF is beyond the scope of this review. Nevertheless, a metabolic shift to a more fetal phenotype, i.e. from fatty acid $\beta$-oxidation to glycolysis, is thought to occur in permanent AF, thereby increasing the ratio of ATP produced per used $\mathrm{O}_{2}[12,45]$. Furthermore, increased utilisation of ketone bodies has been reported in AF [82]. Importantly, there is growing evidence suggesting that metabolic substrate usage is dependent on the stage of AF; adenosine monophospahte-activated protein kinase (AMPK), an energy sensor and regulator of several pathways, is thought to protect against metabolic stress by improving both mitochondrial function (control of glycolysis vs. fatty acid $\beta$-oxidation) and intracellular $\mathrm{Ca}^{2+}$ handling $[25,46,66]$. It has been suggested that AMPK activation, and thus its protective effects, occur during paroxysmal AF, but that this phenomenon is lost when AF becomes persistent [46].

\section{Open aspects for future research}

It will be important in future investigations to identify the weakest link(s), i.e. the "limiting factor", in matching ATP supply to demand in long-term AF. Energetic substrate- and oxygen supply, metabolism-related enzyme activity and ETC activity all represent potential culprits, with aspects of the latter two being partially under $\mathrm{Ca}^{2+}$-controlled regulation, as discussed earlier. We suggest that the "limiting factor" may depend on the extent of electrophysiological and structural remodelling and, therefore, the stage of AF. In response to pathological elevations of cardiac workload in the mouse, the mitochondrial transhydrogenase (NNT) is able to support ATP production by reversing its direction, i.e. converting NADPH to NADH, the conformational aspects of which have recently been defined $[53,97]$. This "compensatory" mechanism, however, is at the expense of mitochondrial ROS scavenging and thus net mitochondrial ROS emission increases. Whether a similar situation occurs in chronic AF, 
due to increased and unmet energy requirements, is currently unknown, but this represents a potentially important avenue of research for the future (Fig. 6). Measurements of mitochondrial membrane potential should be included in future investigations, as it has been suggested that initial $\mathrm{Ca}^{2+}$ overload conditions alter the potential, thereby leading to impaired ATP production [67].

\section{The potential role of ROS in atrial fibrillation}

An association between oxidative damage and AF in human tissue was first provided by Mihm and colleagues and it is now widely accepted that $\mathrm{AF}$ is associated with increased oxidative stress $[35,67,85]$. Although there are many pathways that produce ROS in mammalian cells, four major enzymatic systems seem to dominate in cardiac myocytes: mitochondria, NADPH oxidase, uncoupled NO synthase, and xanthine oxidase $[16,91]$. It is believed that atrial remodelling during AF leads to a switch of ROS sources, from NADPH oxidase in early stages to mitochondrial- and eNOS-derived ROS in chronic AF [105]. Furthermore, mitochondrial ROS have been implicated in cardiac fibrosis, which is a hallmark of AF [40]. There is evidence suggesting that mitochondria play an important role in redox imbalance in post-operative AF, where increased levels of ROS and MnSOD activity, as well as increased sensitivity to mPTP opening, were observed $[4,87]$. Monoamine oxidase in the outer mitochondrial membrane produces $\mathrm{H}_{2} \mathrm{O}_{2}$, and an increase in its activity may be a potential predictive marker for poAF [4]. A decrease in antioxidant-related gene expression and an increase in ROS-related gene expression have been observed in patients with permanent AF [55]. ROS
Fig. 6 Hypothesis of net ROS production during atrial fibrillation with a focus on mitochondrial $\mathrm{Ca}^{2+}$ handling. ATP requirement is increased during atrial fibrillation (due to increased workload), causing a "pull" on the electron transport chain (ETC) (left). Due to remodelling, there is inadequate mitochondrial $\mathrm{Ca}^{2+}\left(\left[\mathrm{Ca}^{2+}\right]_{\mathrm{m}}\right)$ to sufficiently increase ATP production, e.g. NADH (nicotinamide adenine dinucleotide) production by the Krebs Cycle. NADPH (nicotinamide adenine dinucleotide phosphate) is converted to NADH by reverse mode NNT (nicotinamide nucleotide transhydrogenase) as a compensatory mechanism, at the expense of NADPH-driven ROS scavenging. Conversely, increased SR Ca ${ }^{2+}$ leak (right) could expose mitochondria to high $\mathrm{Ca}^{2+}$, thereby creating a "push" on the ETC and increasing mitochondrial ROS production such that it exceeds mitochondrial ROS scavenging capacity

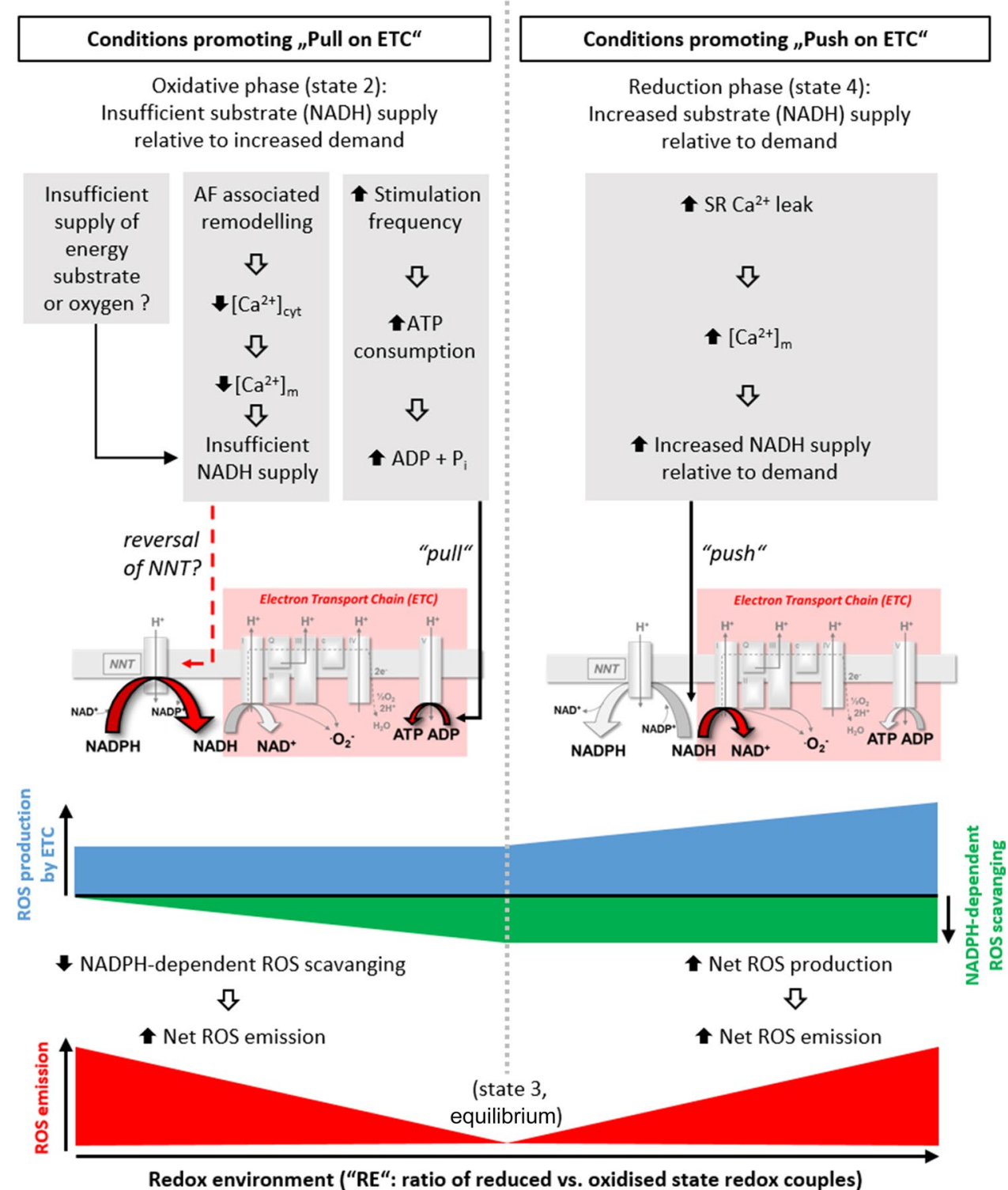

Redox environment ("RE": ratio of reduced vs. oxidised state redox couples) 
production-elimination imbalance in AF leads to morphological and functional changes in the affected human cardiac myocytes, leading to an oxidative vicious cycle [67]. For example, there is evidence that mitochondrial DNA deletion and damage (mtDNA lesions) occurs in human AF [67]. Initial $\mathrm{Ca}^{2+}$ overload and chronic high oxidative stress levels in fibrillating atria may explain the rapid damage of mtDNA.

Atrial fibrillation occurs increasingly with age [65], and ageing results in metabolically dysfunctional cells due to mtDNA deletions [11]. This results in a "mosaic" pattern of dysfunctional cells in the cardiac tissue of mice, causing a pro-arrhythmic substrate [11]. A rapid pacing investigation by Bukowska and colleagues linked tachycardia and tachyarrhythmia with mitochondrial dysfunction and oxidative stress [22]. Furthermore, the Marks group suggested a role of ROS in atrial arrhythmogenesis: mice with a phosphomimetic mutation of RyR2 exhibited higher susceptibility to pacing-induced AF and, furthermore, mitochondrial ROS levels were also higher than in wildtype. An association between increased ROS levels and higher prevalence of arrhythmia was suggested by blunting of ROS after crossing the model with another mouse line overexpressing mitochondrial catalase. These mice did not show increased $\mathrm{Ca}^{2+}$ leak or increased AF susceptibility, despite the RyR mutation, thus supporting evidence already found in ventricle, that RyR oxidation leads to pro-arrhythmic activity [28, 124]. Therefore, a vicious cycle can develop between ROS and disturbed $\mathrm{Ca}^{2+}$ handling, whereby increased SR $\mathrm{Ca}^{2+}$ leak could impair mitochondrial function, leading to increased ROS production which triggers further $\mathrm{Ca}^{2+}$ leak [124].

\section{Open aspects for future research}

The exact mechanism by which pro-arrhythmic cytosolic $\mathrm{Ca}^{2+}$ dynamics would impair mitochondrial function has yet to be fully resolved. However, we hypothesise that large alterations of cytosolic $\mathrm{Ca}^{2+}$, caused by increased $\mathrm{Ca}^{2+}$ leak from the $\mathrm{SR}$, or upon defibrillation or during reperfusion after an ischaemic period, may result in a "push" condition at the ETC, as opposed to the aforementioned "pull". This could increase the production of ${ }^{\circ} \mathrm{O}_{2}{ }^{-}$, thereby changing the redox environment to a state where rate of mitochondrial ROS production exceeds the rate of ROS scavenging, thus resulting in net mitochondrial ROS emission (Fig. 6). A recent study demonstrated that optimising mitochondrial activity pharmacologically with SS31 (a stabiliser of cardiolipin and, therefore, ETC activity) and by pharmacologically preventing increased $\mathrm{Ca}^{2+}$ influx can protect against the effects of tachypacing [120]. Initial findings in human also suggested CaMKII oxidation (and thus activation) by ROS as an important link between oxidative stress and AF [102]. As CaMKII can become constitutively active through this mechanism, this may represent another way in which oxidative stress could underlie chronic atrial pathology [36].

A further perpetuating cycle, involving mitochondria and suggested to play a role in myocardial pathologies, is the so-called ROS-induced ROS release (RIRR), as reviewed by Zorov et al. [131]; ROS activate the MPTP, inner membrane anion channel and ATP-sensitive $\mathrm{K}^{+}$channel, thereby dissipating $\Delta \Psi_{\mathrm{m}}[7,126,127,130]$. The consequence of this is that NADH and NADPH (via reverse NNT) must be used to restore $\Delta \Psi_{\mathrm{m}}$ at the expense of the mitochondrial ROS-scavenging system, thus increasing mitochondrial ROS emission. Furthermore, when open, the MPTP and inner membrane anion channel are permeable to ROS, which can then propagate in the cytosol, potentiating ROS formation and release from neighbouring mitochondria [16, 127]. One would imagine the effect of diffusing ROS is greater in areas of high mitochondrial density and indeed electron microscopic analysis of human atria revealed mitochondrial aggregation in AF [108]. At times of high oxidative stress, for example in heart failure, cross-talk between different ROS sources likely amplifies the ROS signal [73]. Permanent collapse of $\Delta \Psi_{\mathrm{m}}$ induces cell death; however, the metabolic oscillations, caused by increased ROS and RIRR, induce arrhythmia in ventricle [2]. Whether RIRR also underlies pro-arrhythmic activity in the atria during AF is still unresolved; however, this remains an interesting line of investigation.

\section{Summary and conclusions}

The limited understanding of cellular and molecular mechanisms governing AF pathophysiology impedes the development of effective target-specific therapeutic strategies. In the present review, we focussed on the potential role that mitochondria may play in AF. Mitochondrial energetics, $\mathrm{Ca}^{2+}$ handling and ROS dynamics all represent major targets for future research, as it is conceivable that the redox environment plays a crucial role during AF. In the current review, we discussed a hypothesis that remodelling and increased energy demand during AF lead to oxidative stress, shifting the redox environment to a state of energy deficit and compromised ROS scavenging capacity (reverse NNT hypothesis), a similar scenario as has been suggested for heart failure [97] (Fig. 6). On the other hand, we also hypothesise that in conditions of "Ca ${ }^{2+}$ overload", as may occur upon increased intracellular leak, or upon ischaemia reperfusion or defibrillation, mitochondria may experience the other extreme of redox environment, which could increase net ROS emission when ROS production exceeds mitochondrial scavenging capacity (Fig. 6). Therefore, it will be of vital importance in the future to ascertain if and what alterations in $\mathrm{Ca}^{2+}$ dynamics-relative to energy demand-occur, how they 
are associated to remodelling processes in AF (cause vs. effect) and how such changes relate to altered mitochondrial ROS emission. Furthermore, the implementation of the correct experimental environment will be crucial for such investigations, as parameters such as excitation frequency, energy substrate supply and oxygen levels will influence mitochondrial energetics and oxidative stress.

Author contributions Conceptualisation: $\mathrm{CM}$ and NV; literature search: FEM, JRDP, and KA; writing-original draft preparation: FEM and JRDP; writing - review and editing: CM and NV; funding acquisition: $\mathrm{CM}$ and $\mathrm{NV}$.

Funding Open Access funding enabled and organized by Projekt DEAL.. The authors' work is supported by research grants from the DZHK to NV (DZHK GOE MD3 and SE181), from the Deutsche Forschungsgemeinschaft (DFG) to CM (Ma 2528/7-1; SFB 894; TRR-219) and NV (VO 1568/3-1, IRTG1816, SFB1002 and under Germany's Excellence Strategy-EXC 2067/1-390729940), from the Else-Kröner-Fresenius Foundation to NV (EKFS 2016_A20) and from the German Ministry of Education and Research to CM (BMBF; 01EO1504)

\section{Complaince with ethical standards}

Conflict of interest The authors declare that they have no conflict of interest.

Open Access This article is licensed under a Creative Commons Attribution 4.0 International License, which permits use, sharing, adaptation, distribution and reproduction in any medium or format, as long as you give appropriate credit to the original author(s) and the source, provide a link to the Creative Commons licence, and indicate if changes were made. The images or other third party material in this article are included in the article's Creative Commons licence, unless indicated otherwise in a credit line to the material. If material is not included in the article's Creative Commons licence and your intended use is not permitted by statutory regulation or exceeds the permitted use, you will need to obtain permission directly from the copyright holder. To view a copy of this licence, visit http://creativecommons.org/licenses/by/4.0/.

\section{References}

1. Ad N, Schneider A, Khaliulin I, Borman JB, Schwalb H (2005) Impaired mitochondrial response to simulated ischemic injury as a predictor of the development of atrial fibrillation after cardiac surgery: in vitro study in human myocardium. J Thorac Cardiovasc Surg 129:41-45. https://doi.org/10.1016/j.jtcvs.2004.03.058

2. Akar FG, Aon MA, Tomaselli GF, O’Rourke B (2005) The mitochondrial origin of postischemic arrhythmias. J Clin Invest 115:3527-3535. https://doi.org/10.1172/JCI25371

3. Ambrus A (2019) An updated view on the molecular pathomechanisms of human dihydrolipoamide dehydrogenase deficiency in light of novel crystallographic evidence. Neurochem Res 44:2307-2313. https://doi.org/10.1007/s11064-019-02766-9

4. Anderson EJ, Efird JT, Davies SW, O’Neal WT, Darden TM, Thayne KA, Katunga LA, Kindell LC, Ferguson TB, Anderson CA, Chitwood WR, Koutlas TC, Williams JM, Rodriguez E, Kypson AP (2014) Monoamine oxidase is a major determinant of redox balance in human atrial myocardium and is associated with postoperative atrial fibrillation. J Am Heart Assoc 3:e000713. https://doi.org/10.1161/JAHA.113.000713

5. Andrade J, Khairy P, Dobrev D, Nattel S (2014) The clinical profile and pathophysiology of atrial fibrillation. Circ Res 114:14531468. https://doi.org/10.1161/CIRCRESAHA.114.303211

6. Andrienko TN, Picht E, Bers DM (2009) Mitochondrial free calcium regulation during sarcoplasmic reticulum calcium release in rat cardiac myocytes. J Mol Cell Cardiol 46:1027-1036. https ://doi.org/10.1016/j.yjmcc.2009.03.015

7. Aon MA, Cortassa S, Marbán E, O’Rourke B (2003) Synchronized whole cell oscillations in mitochondrial metabolism triggered by a local release of reactive oxygen species in cardiac myocytes. J Biol Chem 278:44735-44744. https://doi. org/10.1074/jbc.M302673200

8. Aon MA, Cortassa S, O'Rourke B (2010) Redox-optimized ROS balance: a unifying hypothesis. Biochim Biophys Acta Bioenerg 1797:865-877. https://doi.org/10.1016/j.bbabi o.2010.02.016

9. Balaban RS, Kantor HL, Katz LA, Briggs RW (1986) Relation between work and phosphate metabolite in the in vivo paced mammalian heart. Science (80-) 232:1121-1123. https://doi. org/10.1126/science. 3704638

10. Balaban RS, Nemoto S, Finkel T (2005) Mitochondria, oxidants, and aging. Cell 120:483-495. https://doi.org/10.1016/j. cell.2005.02.001

11. Baris OR, Ederer S, Neuhaus JFG, von Kleist-Retzow J-C, Wunderlich CM, Pal M, Wunderlich FT, Peeva V, Zsurka G, Kunz WS, Hickethier T, Bunck AC, Stöckigt F, Schrickel JW, Wiesner RJ (2015) Mosaic deficiency in mitochondrial oxidative metabolism promotes cardiac arrhythmia during aging. Cell Metab 21:667-677. https://doi.org/10.1016/j.cmet.2015.04.005

12. Barth AS, Merk S, Arnoldi E, Zwermann L, Kloos P, Gebauer M, Steinmeyer K, Bleich M, Kääb S, Hinterseer M, Kartmann H, Kreuzer E, Dugas M, Steinbeck G, Nabauer M (2005) Reprogramming of the human atrial transcriptome in permanent atrial fibrillation. Circ Res 96:1022-1029. https://doi.org/10.1161/01. RES.0000165480.82737.33

13. Barth AS, Tomaselli GF (2009) Cardiac metabolism and arrhythmias. Circ Arrhythmia Electrophysiol 2:327-335. https://doi. org/10.1161/CIRCEP.108.817320

14. Bay J, Kohlhaas M, Maack C (2013) Intracellular $\mathrm{Na}^{+}$and cardiac metabolism. J Mol Cell Cardiol 61:20-27. https://doi. org/10.1016/j.yjmcc.2013.05.010

15. Bers DM (2002) Cardiac excitation-contraction coupling. Nature 415:198-205. https://doi.org/10.1038/415198a

16. Bertero E, Maack C (2018) Calcium signaling and reactive oxygen species in mitochondria. Circ Res 122:1460-1478. https:// doi.org/10.1161/CIRCRESAHA.118.310082

17. Beutner G, Sharma VK, Lin L, Ryu S-Y, Dirksen RT, Sheu $S-S$ (2005) Type 1 ryanodine receptor in cardiac mitochondria: transducer of excitation-metabolism coupling. Biochim Biophys Acta Biomembr 1717:1-10. https://doi.org/10.1016/j.bbame m.2005.09.016

18. Bhosale G, Sharpe JA, Sundier SY, Duchen MR (2015) Calcium signaling as a mediator of cell energy demand and a trigger to cell death. Ann N Y Acad Sci 1350:107-116. https://doi. org/10.1111/nyas.12885

19. Bleier L, Dröse S (2013) Superoxide generation by complex III: from mechanistic rationales to functional consequences. Biochim Biophys Acta Bioenerg 1827:1320-1331. https://doi. org/10.1016/j.bbabio.2012.12.002

20. Brandenburg S, Arakel EC, Schwappach B, Lehnart SE (2016) The molecular and functional identities of atrial cardiomyocytes in health and disease. Biochim Biophys Acta Mol Cell Res 1863:1882-1893. https://doi.org/10.1016/j.bbamcr.2015.11.025 
21. De Brito OM, Scorrano L (2008) Mitofusin 2 tethers endoplasmic reticulum to mitochondria. Nature 456:605-610. https://doi. org/10.1038/nature07534

22. Bukowska A, Schild L, Keilhoff G, Hirte D, Neumann M, Gardemann A, Neumann KH, Röhl F-W, Huth C, Goette A, Lendeckel U (2008) Mitochondrial dysfunction and redox signaling in atrial tachyarrhythmia. Exp Biol Med 233:558-574. https:// doi.org/10.3181/0706-RM-155

23. Buntinas L, Gunter KK, Sparagna GC, Gunter TE (2001) The rapid mode of calcium uptake into heart mitochondria (RaM): comparison to RaM in liver mitochondria. Biochim Biophys Acta Bioenerg 1504:248-261. https://doi.org/10.1016/S0005 $-2728(00) 00254-1$

24. Carafoli E, Tiozzo R, Lugli G, Crovetti F, Kratzing C (1974) The release of calcium from heart mitochondria by sodium. J Mol Cell Cardiol 6:361-371. https://doi.org/10.1016/00222828(74)90077-7

25. Chakraborty P, Nattel S, Nanthakumar K (2020) Linking cellular energy state to atrial fibrillation pathogenesis: potential role of adenosine monophosphate-activated protein kinase. Hear Rhythm 17:1398-1404. https://doi.org/10.1016/j.hrthm .2020 .03 .025

26. Chen Y, Csordás G, Jowdy C, Schneider TG, Csordás N, Wang W, Liu Y, Kohlhaas M, Meiser M, Bergem S, Nerbonne JM, Dorn GW, Maack C (2012) Mitofusin 2-containing mitochondrial-reticular microdomains direct rapid cardiomyocyte bioenergetic responses via interorganelle $\mathrm{Ca}^{2+}$ crosstalk. Circ Res 111:863-875. https://doi.org/10.1161/CIRCRESAHA.112.26658 5

27. Chiang DY, Li N, Wang Q, Alsina KM, Quick AP, Reynolds JO, Wang G, Skapura D, Voigt N, Dobrev D, Wehrens XHT (2014) Impaired local regulation of ryanodine receptor type 2 by protein phosphatase 1 promotes atrial fibrillation. Cardiovasc Res 103:178-187. https://doi.org/10.1093/cvr/cvu123

28. Cooper LL, Li W, Lu Y, Centracchio J, Terentyeva R, Koren G, Terentyev D (2013) Redox modification of ryanodine receptors by mitochondria-derived reactive oxygen species contributes to aberrant $\mathrm{Ca}^{2+}$ handling in ageing rabbit hearts. J Physiol 591:5895-5911. https://doi.org/10.1113/jphysiol.2013.260521

29. Cortassa S, Aon MA, Winslow RL, O'Rourke B (2004) A mitochondrial oscillator dependent on reactive oxygen species. Biophys J 87:2060-2073. https://doi.org/10.1529/bioph ysj.104.041749

30. Cortassa S, O'Rourke B, Aon MA (2014) Redox-optimized ROS balance and the relationship between mitochondrial respiration and ROS. Biochim Biophys Acta Bioenerg 1837:287-295. https ://doi.org/10.1016/j.bbabio.2013.11.007

31. Crompton M (1999) The mitochondrial permeability transition pore and its role in cell death. Biochem J 341:233-249. https:// doi.org/10.1042/0264-6021:3410233

32. Denham NC, Pearman CM, Caldwell JL, Madders GWP, Eisner DA, Trafford AW, Dibb KM (2018) Calcium in the pathophysiology of atrial fibrillation and heart failure. Front Physiol 9:1380. https://doi.org/10.3389/fphys.2018.01380

33. Dobrev D, Carlsson L, Nattel S (2012) Novel molecular targets for atrial fibrillation therapy. Nat Rev Drug Discov 11:275-291. https://doi.org/10.1038/nrd3682

34. Edwards JN, Blatter LA (2014) Cardiac alternans and intracellular calcium cycling. Clin Exp Pharmacol Physiol 41:524-532. https://doi.org/10.1111/1440-1681.12231

35. Emelyanova L, Ashary Z, Cosic M, Negmadjanov U, Ross G, Rizvi F, Olet S, Kress D, Sra J, Tajik AJ, Holmuhamedov EL, Shi Y, Jahangir A (2016) Selective downregulation of mitochondrial electron transport chain activity and increased oxidative stress in human atrial fibrillation. Am J Physiol Circ Physiol 311:H54H63. https://doi.org/10.1152/ajpheart.00699.2015

36. Erickson JR, Joiner MA, Guan X, Kutschke W, Yang J, Oddis CV, Bartlett RK, Lowe JS, O’Donnell SE, Aykin-Burns N, Zimmerman MC, Zimmerman K, Ham A-JL, Weiss RM, Spitz DR, Shea MA, Colbran RJ, Mohler PJ, Anderson ME (2008) A dynamic pathway for calcium-independent activation of CaMKII by methionine oxidation. Cell 133:462-474. https://doi. org/10.1016/j.cell.2008.02.048

37. Fakuade FE, Steckmeister V, Seibertz F, Gronwald J, Kestel S, Menzel J, Pronto JRD, Taha K, Haghighi F, Kensah G, Pearman CM, Wiedmann F, Teske AJ, Schmidt C, Dibb KM, El-Essawi A, Danner BC, Baraki H, Schwappach B, Kutschka I, Mason FE, Voigt N (2020) Altered atrial cytosolic calcium handling contributes to the development of postoperative atrial fibrillation. Cardiovasc Res In Press. https://doi.org/10.1093/cvr/cvaa162

38. Fernandez-Sanz C, Ruiz-Meana M, Miro-Casas E, Nuñez E, Castellano J, Loureiro M, Barba I, Poncelas M, Rodriguez-Sinovas A, Vázquez J, Garcia-Dorado D (2014) Defective sarcoplasmic reticulum-mitochondria calcium exchange in aged mouse myocardium. Cell Death Dis 5:e1573-e1573. https://doi.org/10.1038/ cddis. 2014.526

39. Filadi R, Greotti E, Turacchio G, Luini A, Pozzan T, Pizzo P (2015) Mitofusin 2 ablation increases endoplasmic reticulummitochondria coupling. Proc Natl Acad Sci 112:E2174-E2181. https://doi.org/10.1073/pnas.1504880112

40. Friedrichs K, Baldus S, Klinke A (2012) Fibrosis in atrial fibrillation-role of reactive species and MPO. Front Physiol 3:214. https://doi.org/10.3389/fphys.2012.00214

41. Garbincius JF, Luongo TS, Elrod JW (2020) The debate continues-what is the role of MCU and mitochondrial calcium uptake in the heart? J Mol Cell Cardiol. https://doi.org/10.1016/j.yjmcc .2020.04.029

42. Goh KY, Qu J, Hong H, Liu T, Dell'Italia LJ, Wu Y, O'Rourke B, Zhou L (2016) Impaired mitochondrial network excitability in failing guinea-pig cardiomyocytes. Cardiovasc Res 109:79-89. https://doi.org/10.1093/cvr/cvv230

43. Greiser M, Schotten U (2013) Dynamic remodeling of intracellular $\mathrm{Ca}^{2+}$ signaling during atrial fibrillation. J Mol Cell Cardiol 58:134-142. https://doi.org/10.1016/j.yjmcc.2012.12.020

44. Halestrap AP (2009) What is the mitochondrial permeability transition pore? J Mol Cell Cardiol 46:821-831. https://doi. org/10.1016/j.yjmcc.2009.02.021

45. Harada M, Melka J, Sobue Y, Nattel S (2017) Metabolic considerations in atrial fibrillation-mechanistic insights and therapeutic opportunities. Circ J 81:1749-1757. https://doi.org/10.1253/ circj.CJ-17-1058

46. Harada M, Tadevosyan A, Qi X, Xiao J, Liu T, Voigt N, Karck M, Kamler M, Kodama I, Murohara T, Dobrev D, Nattel S (2015) Atrial fibrillation activates AMP-dependent protein kinase and its regulation of cellular calcium handling. J Am Coll Cardiol 66:47-58. https://doi.org/10.1016/j.jacc.2015.04.056

47. Harrington JL, Murphy E (2015) The mitochondrial calcium uniporter: mice can live and die without it. J Mol Cell Cardiol 78:46-53. https://doi.org/10.1016/j.yjmcc.2014.10.013

48. Heijman J, Voigt N, Dobrev D (2013) New directions in antiarrhythmic drug therapy for atrial fibrillation. Future Cardiol 9:71-88. https://doi.org/10.2217/fca.12.78

49. Heijman J, Voigt N, Nattel S, Dobrev D (2014) Cellular and molecular electrophysiology of atrial fibrillation initiation, maintenance, and progression. Circ Res 114:1483-1499. https://doi. org/10.1161/CIRCRESAHA.114.302226

50. Heijman J, Voigt N, Wehrens XHT, Dobrev D (2014) Calcium dysregulation in atrial fibrillation: the role of CaMKII. Front Pharmacol 5:30. https://doi.org/10.3389/fphar.2014.00030 
51. Heinzel FR, Luo Y, Dodoni G, Boengler K, Petrat F, Di Lisa F, de Groot H, Schulz R, Heusch G (2006) Formation of reactive oxygen species at increased contraction frequency in rat cardiomyocytes. Cardiovasc Res 71:374-382. https://doi.org/10.1016/j. cardiores.2006.05.014

52. Hove-Madsen L, Llach A, Bayes-Genís A, Roura S, Font ER, Arís A, Cinca J (2004) Atrial fibrillation is associated with increased spontaneous calcium release from the sarcoplasmic reticulum in human atrial myocytes. Circulation 110:1358-1363. https://doi.org/10.1161/01.CIR.0000141296.59876.87

53. Kampjut D, Sazanov LA (2019) Structure and mechanism of mitochondrial proton-translocating transhydrogenase. Nature 573:291-295. https://doi.org/10.1038/s41586-019-1519-2

54. Kanaan GN, Patten DA, Redpath CJ, Harper M-E (2019) Atrial fibrillation is associated with impaired atrial mitochondrial energetics and supercomplex formation in adults with type 2 diabetes. Can J Diabetes 43:67-75.e1. https://doi.org/10.1016/j. jcjd.2018.05.007

55. Kim YH, Lim DS, Lee JH, Shim WJ, Ro YM, Park GH, Becker KG, Cho-Chung YS, Kim M (2003) Gene expression profiling of oxidative stress on atrial fibrillation in humans. Exp Mol Med 35:336-349. https://doi.org/10.1038/emm.2003.45

56. Kohlhaas M, Liu T, Knopp A, Zeller T, Ong MF, Böhm M, O'Rourke B, Maack C (2010) Elevated cytosolic $\mathrm{Na}^{+}$increases mitochondrial formation of reactive oxygen species in failing cardiac myocytes. Circulation 121:1606-1613. https://doi. org/10.1161/CIRCULATIONAHA.109.914911

57. Kohlhaas M, Maack C (2010) Adverse bioenergetic consequences of $\mathrm{Na}^{+}-\mathrm{Ca}^{2+}$ exchanger-mediated $\mathrm{Ca}^{2+}$ Influx in Cardiac myocytes. Circulation 122:2273-2280. https://doi.org/10.1161/ CIRCULATIONAHA.110.968057

58. Kohlhaas M, Maack C (2013) Calcium release microdomains and mitochondria. Cardiovasc Res 98:259-268. https://doi. org/10.1093/cvr/cvt032

59. Kohlhaas M, Nickel AG, Maack C (2017) Mitochondrial energetics and calcium coupling in the heart. J Physiol 595:3753-3763. https://doi.org/10.1113/JP273609

60. Krumova K, Cosa G (2016) Chapter 1. Overview of reactive oxygen species. in: singlet oxygen: applications in biosciences and nanosciences, vol 1. The Royal Society of Chemistry, pp $1-21$

61. Kwong JQ, Lu X, Correll RN, Schwanekamp JA, Vagnozzi RJ, Sargent MA, York AJ, Zhang J, Bers DM, Molkentin JD (2015) The mitochondrial calcium uniporter selectively matches metabolic output to acute contractile stress in the heart. Cell Rep 12:15-22. https://doi.org/10.1016/j.celrep.2015.06.002

62. De La Fuente S, Lambert JP, Nichtova Z, Fernandez Sanz C, Elrod JW, Sheu S-S, Csordás G (2018) Spatial separation of mitochondrial calcium uptake and extrusion for energy-efficient mitochondrial calcium signaling in the heart. Cell Rep 24:30993107.e4. https://doi.org/10.1016/j.celrep.2018.08.040

63. De La Fuente S, Sheu S-S (2019) SR-mitochondria communication in adult cardiomyocytes: a close relationship where the $\mathrm{Ca}^{2+}$ has a lot to say. Arch Biochem Biophys 663:259-268. https://doi. org/10.1016/j.abb.2019.01.026

64. Lardy HA, Wellman H (1952) Oxidative phosphorylations; role of inorganic phosphate and acceptor systems in control of metabolic rates. J Biol Chem 195:215-224

65. Laredo M, Waldmann V, Khairy P, Nattel S (2018) Age as a critical determinant of atrial fibrillation: a two-sided relationship. Can J Cardiol 34:1396-1406. https://doi.org/10.1016/j. cjca.2018.08.007

66. Lenski M, Schleider G, Kohlhaas M, Adrian L, Adam O, Tian Q, Kaestner L, Lipp P, Lehrke M, Maack C, Böhm M, Laufs U (2015) Arrhythmia causes lipid accumulation and reduced glucose uptake. Basic Res Cardiol 110:40. https://doi. org/10.1007/s00395-015-0497-2

67. Lin P-H, Lee S-H, Su C-P, Wei Y-H (2003) Oxidative damage to mitochondrial DNA in atrial muscle of patients with atrial fibrillation. Free Radic Biol Med 35:1310-1318. https://doi. org/10.1016/j.freeradbiomed.2003.07.002

68. Lipp P, Laine M, Tovey SC, Burrell KM, Berridge MJ, Li W, Bootman MD (2000) Functional InsP $\mathrm{P}_{3}$ receptors that may modulate excitation-contraction coupling in the heart. Curr Biol 10:939-942. https://doi.org/10.1016/S0960-9822(00)00624-2

69. Lu X, Ginsburg KS, Kettlewell S, Bossuyt J, Smith GL, Bers DM (2013) Measuring local gradients of intramitochondrial $\left[\mathrm{Ca}^{2+}\right]$ in cardiac myocytes during sarcoplasmic reticulum $\mathrm{Ca}^{2+}$ release. Circ Res 112:424-431. https://doi.org/10.1161/CIRCRESAHA .111 .300501

70. Lu X, Kwong JQ, Molkentin JD, Bers DM (2016) Individual cardiac mitochondria undergo rare transient permeability transition pore openings. Circ Res 118:834-841. https://doi.org/10.1161/ CIRCRESAHA.115.308093

71. Luongo TS, Lambert JP, Gross P, Nwokedi M, Lombardi AA, Shanmughapriya S, Carpenter AC, Kolmetzky D, Gao E, van Berlo JH, Tsai EJ, Molkentin JD, Chen X, Madesh M, Houser SR, Elrod JW (2017) The mitochondrial $\mathrm{Na}^{+} / \mathrm{Ca}^{2+}$ exchanger is essential for $\mathrm{Ca}^{2+}$ homeostasis and viability. Nature 545:93-97. https://doi.org/10.1038/nature22082

72. Maack C (2016) Orphaned mitochondria in heart failure. Cardiovasc Res 109:6-8. https://doi.org/10.1093/cvr/cvv262

73. Maack C, Böhm M (2011) Targeting mitochondrial oxidative stress in heart failure. J Am Coll Cardiol 58:83-86. https://doi. org/10.1016/j.jacc.2011.01.032

74. Maack C, Cortassa S, Aon MA, Ganesan AN, Liu T, O'Rourke $B$ (2006) Elevated cytosolic $\mathrm{Na}^{+}$decreases mitochondrial $\mathrm{Ca}^{2+}$ uptake during excitation-contraction coupling and impairs energetic adaptation in cardiac myocytes. Circ Res 99:172-182. https ://doi.org/10.1161/01.RES.0000232546.92777.05

75. Maack C, O'Rourke B (2007) Excitation-contraction coupling and mitochondrial energetics. Basic Res Cardiol 102:369-392. https://doi.org/10.1007/s00395-007-0666-Z

76. Mackenzie L, Bootman MD, Laine M, Berridge MJ, Thuring J, Holmes A, Li W-H, Lipp P (2002) The role of inositol 1,4,5-trisphosphate receptors in $\mathrm{Ca}^{2+}$ signalling and the generation of arrhythmias in rat atrial myocytes. J Physiol 541:395-409. https ://doi.org/10.1113/jphysiol.2001.013411

77. Mackenzie L, Roderick HL, Berridge MJ, Conway SJ, Bootman MD (2004) The spatial pattern of atrial cardiomyocyte calcium signalling modulates contraction. J Cell Sci 117:6327-6337. https://doi.org/10.1242/jcs.01559

78. Marín-García J, Goldenthal MJ, Moe GW (2001) Abnormal cardiac and skeletal muscle mitochondrial function in pacinginduced cardiac failure. Cardiovasc Res 52:103-110. https://doi. org/10.1016/S0008-6363(01)00368-6

79. Mary-Rabine L, Albert A, Pham TD, Hordof A, Fenoglio JJ, Malm JR, Rosen MR (1983) The relationship of human atrial cellular electrophysiology to clinical function and ultrastructure. Circ Res 52:188-199. https://doi.org/10.1161/01.RES.52.2.188

80. Mason FE, Sossalla S (2017) The significance of the late $\mathrm{Na}^{+}$ current for arrhythmia induction and the therapeutic antiarrhythmic potential of ranolazine. J Cardiovasc Pharmacol Ther 22:40-50. https://doi.org/10.1177/1074248416644989

81. Mathew ST, Patel J, Joseph S (2009) Atrial fibrillation: mechanistic insights and treatment options. Eur J Intern Med 20:672681. https://doi.org/10.1016/j.ejim.2009.07.011

82. Mayr M, Yusuf S, Weir G, Chung Y-L, Mayr U, Yin X, Ladroue C, Madhu B, Roberts N, De Souza A, Fredericks S, Stubbs M, Griffiths JR, Jahangiri M, Xu Q, Camm AJ (2008) Combined metabolomic and proteomic analysis of human atrial fibrillation. 
J Am Coll Cardiol 51:585-594. https://doi.org/10.1016/j. jacc.2007.09.055

83. McCormack JG, Halestrap AP, Denton RM (1990) Role of calcium ions in regulation of mammalian intramitochondrial metabolism. Physiol Rev 70:391-425. https://doi.org/10.1152/ physrev.1990.70.2.391

84. McNutt NS, Fawcett DW (1969) The ultrastructure of the cat myocardium. J Cell Biol 42:46-67. https://doi.org/10.1083/ jcb.42.1.46

85. Mihm MJ, Yu F, Carnes CA, Reiser PJ, McCarthy PM, Van Wagoner DR, Bauer JA (2001) Impaired myofibrillar energetics and oxidative injury during human atrial fibrillation. Circulation 104:174-180. https://doi.org/10.1161/01.CIR.104.2.174

86. Min CK, Yeom DR, Lee K-E, Kwon H-K, Kang M, Kim Y-S, Park ZY, Jeon H, Kim DH (2012) Coupling of ryanodine receptor 2 and voltage-dependent anion channel 2 is essential for $\mathrm{Ca}^{2+}$ transfer from the sarcoplasmic reticulum to the mitochondria in the heart. Biochem J 447:371-379. https://doi.org/10.1042/ BJ20120705

87. Montaigne D, Marechal X, Lefebvre P, Modine T, Fayad G, Dehondt H, Hurt C, Coisne A, Koussa M, Remy-Jouet I, Zerimech F, Boulanger E, Lacroix D, Staels B, Neviere R (2013) Mitochondrial dysfunction as an arrhythmogenic substrate. J Am Coll Cardiol 62:1466-1473. https://doi.org/10.1016/j. jacc.2013.03.061

88. Mozaffarian D, Benjamin EJ, Go AS, Arnett DK, Blaha MJ, Cushman M, de Ferranti S, Després J-P, Fullerton HJ, Howard VJ, Huffman MD, Judd SE, Kissela BM, Lackland DT, Lichtman JH, Lisabeth LD, Liu S, Mackey RH, Matchar DB, McGuire DK, Mohler ER, Moy CS, Muntner P, Mussolino ME, Nasir K, Neumar RW, Nichol G, Palaniappan L, Pandey DK, Reeves MJ, Rodriguez CJ, Sorlie PD, Stein J, Towfighi A, Turan TN, Virani SS, Willey JZ, Woo D, Yeh RW, Turner MB (2015) Heart disease and stroke statistics-2015 update: a report from the american heart association. Circulation 131:e29-322. https://doi.org/10.1161/ CIR.0000000000000152

89. Murphy AN, Kelleher JK, Fiskum G (1990) Submicromolar $\mathrm{Ca}^{2+}$ regulates phosphorylating respiration by normal rat liver and AS-30D hepatoma mitochondria by different mechanisms. J Biol Chem 265:10527-10534

90. Murphy E, Eisner DA (2009) Regulation of intracellular and mitochondrial sodium in health and disease. Circ Res 104:292303. https://doi.org/10.1161/CIRCRESAHA.108.189050

91. Murphy MP (2009) How mitochondria produce reactive oxygen species. Biochem J 417:1-13. https://doi.org/10.1042/BJ200 81386

92. Naon D, Zaninello M, Giacomello M, Varanita T, Grespi F, Lakshminaranayan S, Serafini A, Semenzato M, Herkenne S, Hernández-Alvarez MI, Zorzano A, De Stefani D, Dorn GW, Scorrano L (2016) Critical reappraisal confirms that Mitofusin 2 is an endoplasmic reticulum-mitochondria tether. Proc Natl Acad Sci 113:11249-11254. https://doi.org/10.1073/pnas.1606786113

93. Naon D, Zaninello M, Giacomello M, Varanita T, Grespi F, Lakshminaranayan S, Serafini A, Semenzato M, Herkenne S, Hernández-Alvarez MI, Zorzano A, De Stefani D, Dorn GW, Scorrano L (2017) Reply to Filadi et al.: does Mitofusin 2 tether or separate endoplasmic reticulum and mitochondria? Proc Natl Acad Sci 114:E2268-E2269. https://doi.org/10.1073/pnas.16186 10114

94. Nattel S (2017) Molecular and cellular mechanisms of atrial fibrosis in atrial fibrillation. JACC Clin Electrophysiol 3:425435. https://doi.org/10.1016/j.jacep.2017.03.002

95. Neef S, Dybkova N, Sossalla S, Ort KR, Fluschnik N, Neumann K, Seipelt R, Schöndube FA, Hasenfuss G, Maier LS (2010) CaMKII-dependent diastolic SR $\mathrm{Ca}^{2+}$ leak and elevated diastolic $\mathrm{Ca}^{2+}$ levels in right atrial myocardium of patients with atrial fibrillation. Circ Res 106:1134-1144. https://doi.org/10.1161/ CIRCRESAHA.109.203836

96. Nickel A, Kohlhaas M, Maack C (2014) Mitochondrial reactive oxygen species production and elimination. J Mol Cell Cardiol $73: 26-33$

97. Nickel AG, von Hardenberg A, Hohl M, Löffler JR, Kohlhaas M, Becker J, Reil J-C, Kazakov A, Bonnekoh J, Stadelmaier M, Puhl S-L, Wagner M, Bogeski I, Cortassa S, Kappl R, Pasieka B, Lafontaine M, Lancaster CRD, Blacker TS, Hall AR, Duchen MR, Kästner L, Lipp P, Zeller T, Müller C, Knopp A, Laufs U, Böhm M, Hoth M, Maack C (2015) Reversal of mitochondrial transhydrogenase causes oxidative stress in heart failure. Cell Metab 22:472-484. https://doi.org/10.1016/j.cmet.2015.07.008

98. O'Rourke B, Ramza BM, Marban E (1994) Oscillations of membrane current and excitability driven by metabolic oscillations in heart cells. Science (80-) 265:962-966. https://doi. org/10.1126/science.8052856

99. Opacic D, van Bragt KA, Nasrallah HM, Schotten U, Verheule S (2016) Atrial metabolism and tissue perfusion as determinants of electrical and structural remodelling in atrial fibrillation. Cardiovasc Res 109:527-541. https://doi.org/10.1093/ cvr/cvw007

100. Palty R, Silverman WF, Hershfinkel M, Caporale T, Sensi SL, Parnis J, Nolte C, Fishman D, Shoshan-Barmatz V, Herrmann S, Khananshvili D, Sekler I (2010) NCLX is an essential component of mitochondrial $\mathrm{Na}^{+} / \mathrm{Ca}^{2+}$ exchange. Proc Natl Acad Sci 107:436-441. https://doi.org/10.1073/pnas.0908099107

101. Pearman CM, Madders GWP, Radcliffe EJ, Kirkwood GJ, Lawless M, Watkins A, Smith CER, Trafford AW, Eisner DA, Dibb KM (2018) Increased vulnerability to atrial fibrillation is associated with increased susceptibility to alternans in old sheep. J Am Heart Assoc 7:e009972. https://doi.org/10.1161/ JAHA.118.009972

102. Purohit A, Rokita AG, Guan X, Chen B, Koval OM, Voigt N, Neef S, Sowa T, Gao Z, Luczak ED, Stefansdottir H, Behunin AC, Li N, El-Accaoui RN, Yang B, Swaminathan PD, Weiss RM, Wehrens XHT, Song L-S, Dobrev D, Maier LS, Anderson ME (2013) Oxidized $\mathrm{Ca}^{2+} /$ calmodulin-dependent protein kinase ii triggers atrial fibrillation. Circulation 128:1748-1757. https://doi.org/10.1161/CIRCULATIONAHA.113.003313

103. Quinlan CL, Goncalves RLS, Hey-Mogensen M, Yadava N, Bunik VI, Brand MD (2014) The 2-oxoacid dehydrogenase complexes in mitochondria can produce superoxide/hydrogen peroxide at much higher rates than complex I. J Biol Chem 289:8312-8325. https://doi.org/10.1074/jbc.M113.545301

104. Rapizzi E, Pinton P, Szabadkai G, Wieckowski MR, Vandecasteele G, Baird G, Tuft RA, Fogarty KE, Rizzuto R (2002) Recombinant expression of the voltage-dependent anion channel enhances the transfer of $\mathrm{Ca}^{2+}$ microdomains to mitochondria. $\mathrm{J}$ Cell Biol 159:613-624. https://doi.org/10.1083/jcb.200205091

105. Reilly SN, Jayaram R, Nahar K, Antoniades C, Verheule S, Channon KM, Alp NJ, Schotten U, Casadei B (2011) Atrial sources of reactive oxygen species vary with the duration and substrate of atrial fibrillation. Circulation 124:1107-1117. https://doi. org/10.1161/CIRCULATIONAHA.111.029223

106. Seidlmayer LK, Kuhn J, Berbner A, Arias-Loza P-A, Williams T, Kaspar M, Czolbe M, Kwong JQ, Molkentin JD, Heinze KG, Dedkova EN, Ritter O (2016) Inositol 1,4,5-trisphosphatemediated sarcoplasmic reticulum-mitochondrial crosstalk influences adenosine triphosphate production via mitochondrial $\mathrm{Ca}^{2+}$ uptake through the mitochondrial ryanodine receptor in cardiac myocytes. Cardiovasc Res 112:491-501. https://doi.org/10.1093/ cvr/cvw185

107. Seidlmayer LK, Mages C, Berbner A, Eder-Negrin P, Arias-Loza PA, Kaspar M, Song M, Dorn GW, Kohlhaas M, Frantz S, Maack C, Gerull B, Dedkova EN (2019) Mitofusin 2 is essential for 
$\mathrm{IP}_{3}$-mediated SR/mitochondria metabolic feedback in ventricular myocytes. Front Physiol 10:733. https://doi.org/10.3389/fphys .2019 .00733

108. Sharma S, Sharma G, Hote M, Devagourou V, Kesari V, Arava S, Airan B, Ray R (2014) Light and electron microscopic features of surgically excised left atrial appendage in rheumatic heart disease patients with atrial fibrillation and sinus rhythm. Cardiovasc Pathol 23:319-326. https://doi.org/10.1016/j.carpa th.2014.07.008

109. Sharma VK, Ramesh V, Franzini-Armstrong C, Sheu SS (2000) Transport of $\mathrm{Ca}^{2+}$ from sarcoplasmic reticulum to mitochondria in rat ventricular myocytes. J Bioenerg Biomembr 32:97-104. https://doi.org/10.1023/A:1005520714221

110. Sovari AA (2016) Cellular and molecular mechanisms of arrhythmia by oxidative stress. Cardiol Res Pract 2016:1-7. https://doi. org/10.1155/2016/9656078

111. Stanley WC, Recchia FA, Lopaschuk GD (2005) Myocardial substrate metabolism in the normal and failing heart. Physiol Rev 85:1093-1129. https://doi.org/10.1152/physrev.00006.2004

112. De Stefani D, Raffaello A, Teardo E, Szabò I, Rizzuto R (2011) A forty-kilodalton protein of the inner membrane is the mitochondrial calcium uniporter. Nature 476:336-340. https://doi. org/10.1038/nature10230

113. De Stefani D, Rizzuto R, Pozzan T (2016) Enjoy the trip: calcium in mitochondria back and forth. Annu Rev Biochem 85:161-192. https://doi.org/10.1146/annurev-biochem-060614-034216

114. Territo PR, Mootha VK, French SA, Balaban RS (2000) $\mathrm{Ca}^{2+}$ activation of heart mitochondrial oxidative phosphorylation: role of the $\mathrm{F}_{\mathrm{o}} / \mathrm{F}_{1}$-ATPase. Am J Physiol Physiol 278:C423-C435. https://doi.org/10.1152/ajpcell.2000.278.2.C423

115. Tu T, Zhou S, Liu Z, Li X, Liu Q (2014) Quantitative proteomics of changes in energy metabolism-related proteins in atrial tissue from valvular disease patients with permanent atrial fibrillation. Circ J 78:993-1001. https://doi.org/10.1253/circj.CJ-13-1365

116. Turrens JF, Alexandre A, Lehninger AL (1985) Ubisemiquinone is the electron donor for superoxide formation by complex III of heart mitochondria. Arch Biochem Biophys 237:408-414. https ://doi.org/10.1016/0003-9861(85)90293-0

117. Voigt N, Heijman J, Wang Q, Chiang DY, Li N, Karck M, Wehrens XHT, Nattel S, Dobrev D (2014) Cellular and molecular mechanisms of atrial arrhythmogenesis in patients with paroxysmal atrial fibrillation. Circulation 129:145-156. https://doi. org/10.1161/CIRCULATIONAHA.113.006641

118. Voigt N, Li N, Wang Q, Wang W, Trafford AW, Abu-Taha I, Sun Q, Wieland T, Ravens U, Nattel S, Wehrens XHT, Dobrev D (2012) Enhanced sarcoplasmic reticulum $\mathrm{Ca}^{2+}$ leak and increased $\mathrm{Na}^{+}-\mathrm{Ca}^{2+}$ exchanger function underlie delayed afterdepolarizations in patients with chronic atrial fibrillation. Circulation 125:2059-2070. https://doi.org/10.1161/CIRCULATIO NAHA.111.067306

119. Wagner M, Bertero E, Nickel A, Kohlhaas M, Gibson GE, Heggermont W, Heymans S, Maack C (2020) Selective NADH communication from $\alpha$-ketoglutarate dehydrogenase to mitochondrial transhydrogenase prevents reactive oxygen species formation under reducing conditions in the heart. Basic Res Cardiol 115:53. https://doi.org/10.1007/s00395-020-0815-1

120. Wiersma M, van Marion DMS, Wüst RCI, Houtkooper RH, Zhang D, de Groot NMS, Henning RH, Brundel BJJM (2019) Mitochondrial dysfunction underlies cardiomyocyte remodeling in experimental and clinical atrial fibrillation. Cells 8:1202. https ://doi.org/10.3390/cells8101202

121. Wijesurendra RS, Casadei B (2019) Mechanisms of atrial fibrillation. Heart 105:1860-1867. https://doi.org/10.1136/heartjnl2018-314267

122. Williams GSB, Boyman L, Lederer WJ (2015) Mitochondrial calcium and the regulation of metabolism in the heart. J Mol Cell Cardiol 78:35-45. https://doi.org/10.1016/j.yjmcc.2014.10.019

123. Wilting F, Kopp R, Gurnev PA, Schedel A, Dupper NJ, Kwon O, Nicke A, Gudermann T, Schredelseker J (2020) The antiarrhythmic compound efsevin directly modulates voltage-dependent anion channel 2 by binding to its inner wall and enhancing mitochondrial $\mathrm{Ca}^{2+}$ uptake. Br J Pharmacol 177:2947-2958. https:// doi.org/10.1111/bph.15022

124. Xie W, Santulli G, Reiken SR, Yuan Q, Osborne BW, Chen B-X, Marks AR (2015) Mitochondrial oxidative stress promotes atrial fibrillation. Sci Rep 5:11427. https://doi.org/10.1038/srep11427

125. Yang K-C, Dudley SC (2013) Oxidative stress and atrial fibrillation: finding a missing piece to the puzzle. Circulation 128:17241726. https://doi.org/10.1161/CIRCULATIONAHA.113.005837

126. Zhang DX, Chen Y-F, Campbell WB, Zou A-P, Gross GJ, Li P-L (2001) Characteristics and superoxide-induced activation of reconstituted myocardial mitochondrial ATP-sensitive potassium channels. Circ Res 89:1177-1183. https://doi.org/10.1161/hh240 1.101752

127. Zhou L, Aon MA, Almas T, Cortassa S, Winslow RL, O'Rourke $B$ (2010) A reaction-diffusion model of ROS-induced ROS release in a mitochondrial network. PLoS Comput Biol 6:e1000657. https://doi.org/10.1371/journal.pcbi.1000657

128. Zima AV, Pabbidi MR, Lipsius SL, Blatter LA (2013) Effects of mitochondrial uncoupling on $\mathrm{Ca}^{2+}$ signaling during excitation-contraction coupling in atrial myocytes. Am J Physiol Circ Physiol 304:H983-H993. https://doi.org/10.1152/ajpheart.00932 .2012

129. Zipes DP, Jalife J, Stevenson WG (2017) Cardiac electrophysiology: from cell to bedside, 7th edn. Elsevier, Oxford

130. Zorov DB, Filburn CR, Klotz L-O, Zweier JL, Sollott SJ (2000) Reactive oxygen species (ros-induced) ros release. J Exp Med 192:1001-1014. https://doi.org/10.1084/jem.192.7.1001

131. Zorov DB, Juhaszova M, Sollott SJ (2014) Mitochondrial reactive oxygen species (ROS) and ROS-induced ROS release. Physiol Rev 94:909-950. https://doi.org/10.1152/physrev.00026.2013 